$$
231758
$$

\title{
A Wide Range Modeling Study of Dimethyl Ether Oxidation
}

\author{
H.J. Curran \\ W.J. Pitz \\ N.M. Marinov \\ C.K. Westbrook \\ P. Dagaut \\ J-C Boettner \\ M. Cathonnet
}

This paper was prepared for submittal to the Western States Section/Combustion Institute

Livermore, $C A$

April 14-15, 1997

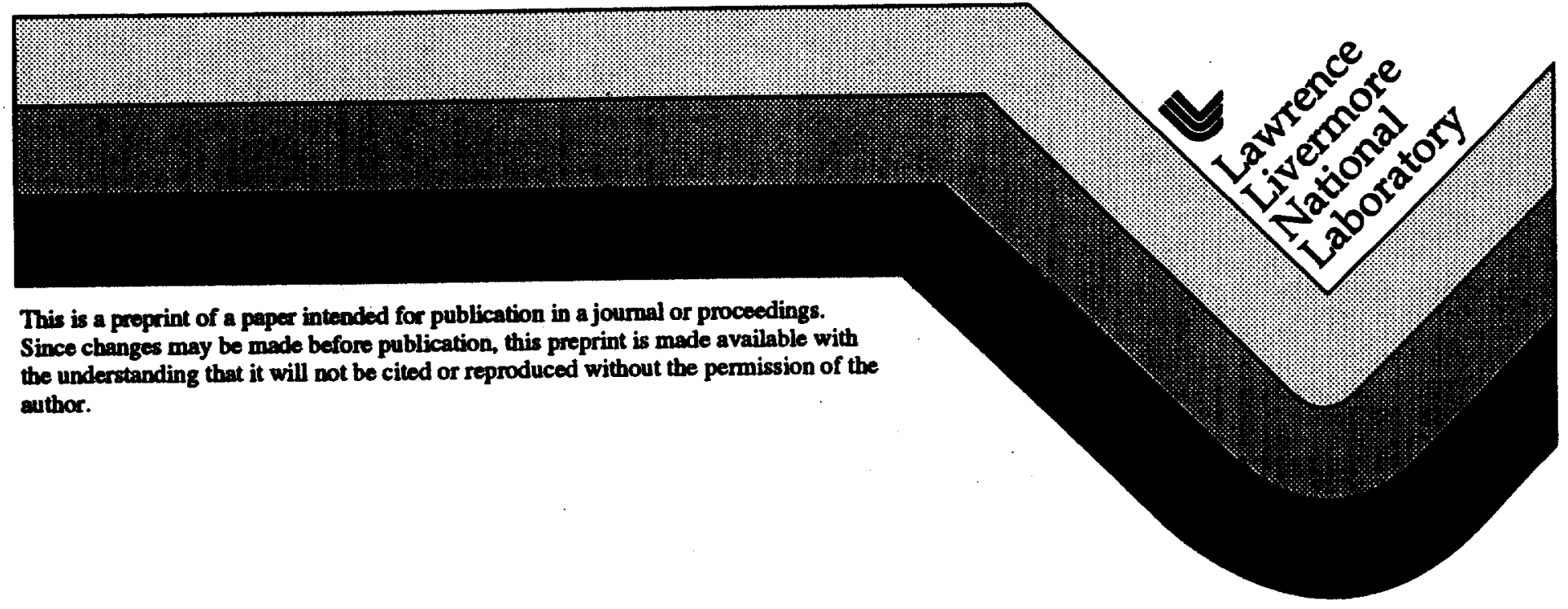


This document was prepared as an account of work aponeored by an agency of the United States Covernment. Neither the United Stmtes Covernment nor the Univerdity of California nor any of their employees, makem any warranty, express or implied, or awumes any legal lisbility or responebility for the eccuracy, completencea, or unefulneas of any information, apparatus, product, or procese diaclosed, or represents that its use would not infringe privately owned rights. Reference hereln to any epectic commercial product, procesen, or service by trede name, trademark, manufacturer, or otherwise, does not necemarily constitute or imply its endoreement, recommendation, of favoring by the United States Covernment of the Univerdity of California. The views and opinions of authors expremed herein do not necewarily state or reflect thowe of the United States Government or the University of Calfornia, and shall not be used for advertining or product endonement purposes. 


\title{
A Wide Range Modeling Study of Dimethyl Ether Oxidation
}

\author{
H. J. Curran, W. J. Pitz, N. M. Marinov and C. K. Westbrook \\ Lawrence Livermore National Laboratory, Livermore, CA 94550 \\ P. Dagaut, J-C Boettner and M. Cathonnet \\ CNRS, \\ Laboratoire de Combustion et Systèmes Réactifs, \\ 45071 Orléans Cedex 2, France
}

\begin{abstract}
A detailed chemical kinetic model has been used to study dimethyl ether (DME) oxidation over a wide range of conditions. Experimental results obtained in a jet-stirred reactor (JSR) at 1 and $10 \mathrm{~atm}, 0.2 \leq \phi \leq 2.5$, and $800 \leq T \leq 1300 \mathrm{~K}$ were modeled, in addition to those generated in a shock tube at 13 and $40 \mathrm{bar}, \phi=1.0$ and $650 \leq T \leq 1300 \mathrm{~K}$. The JSR results are particularly valuable as they include concentration profiles of reactants, intermediates and products pertinent to the oxidation of DME. These data test the kinetic model severely, as it must be able to predict the correct distribution and concentrations of intermediate and final products formed in the oxidation process. Additionally, the shock tube results are very useful, as they were taken at low temperatures and at high pressures, and thus undergo negative temperature dependence (NTC) behaviour. This behaviour is characteristic of the oxidation of saturated hydrocarbon fuels, (e.g. the primary reference fuels, $n$-heptane and isooctane) under similar conditions. The numerical model consists of 78 chemical species and 336 chemical reactions. The thermodynamic properties of unknown species pertaining to DME oxidation were calculated using THERM.
\end{abstract}

\section{Introduction}

Legislative restrictions pertaining to the emission of particulates, volatile organic compounds and $\mathrm{NO}_{\mathbf{x}}$ from internal combustion engines has been increasing in severity in the U.S., Europe and Japan over the past decade. Engine makers and automotive companies have had to look at ways to decrease the emission of these toxic pollutants. Fuel composition affects the tendency of a fuel to form soot particulates and $\mathrm{NO}_{x}$ during combustion; increasing the carbon to hydrogen ratio or the number of carbon-carbon bonds increases the tendency of a fuel to form soot. Dimethyl ether (DME), $\mathrm{CH}_{3} \mathrm{OCH}_{3}$, is the simplest linear ether, has no carbon-carbon bonds and after methane, has the lowest possible carbon to hydrogen ratio. It is a high cetane fuel with a cetane number of 55-60, is not prone to particulate formation and has a low toxicity. Recently, therefore, diesel engines fueled with DME have been tested [1, 2]. It was found that $\mathrm{DME}$ did indeed affect a decrease in the emission of $\mathrm{CO}, \mathrm{NO}_{\mathbf{x}}$, formaldehyde, particulates and nonmethane hydrocarbons [1], compared with commercial diesel fuels. DME has also been successfully used as a methanol ignition improver in diesel engines where it has been reported to dramatically reduce total hydrocarbon emissions [3]. Finally, the technology required for DME handling and use in an engine is that already developed for LPG.

There have been a number of studies which have described the pyrolysis of dimethyl ether [4]-[13] but there have only been three reported kinetic analyses of DME oxidation in laboratory experiments. Sehested et al. [14] have performed experiments in a 140 litre Pyrex reactor at 0.38-940 torr total pressure and at a temperature of $296 \mathrm{~K}$. These experiments are performed at room temperature and up to pressures slightly greater than one atmosphere, but these conditions bear little resemblence to those in an operating diesel engine. Dagaut et al. [15] obtained results in a jet-stirred reactor (JSR) at 1 and 10 atm, $0.2 \leq \phi \leq 2.5$, and $800 \leq T \leq 1300 \mathrm{~K}$. Pfahl and coworkers [16] measured DME igmition delay times behind reflected 
shock waves at 13 and 40 bar, $\phi=1.0$ and $650 \leq T \leq 1300 \mathrm{~K}$. The studies of both Dagaut et al. and Pfahl and coworkers are very valuable as they more closely reflect diesel engine operating conditions. In addition, these latter studies are quite complementary as both were carried out at temperature and pressure ranges which overlap. The shock-tube data extends to lower temperatures and higher pressures where negative temperature coefficient behaviour is observed. Previous modeling work was performed by Dagaut et al. who provided a chemical kinetic mechanism to explain the oxidation of DME under their experimental conditions. We have found in modeling the shock tube data that some of these rate parameters needed to be adjusted and an appropriate low-temperature oxidation scheme added.

\section{Computational Model}

All of the modeling computations in this study were carried out using the HCT modeling code [17]. This code permits the use of a variety of boundary and initial conditions for reactive systems depending on the needs of the particular system being examined. In the case of the JSR, the relevant conditions are those which describe the bulk gases in an homogeneous reactor of constant volume with a prescribed influx of fresh reactants and constant temperature and pressure within the reactor. The shock tube experiments were modeled assuming constant volume behind the reflected shock wave. The detailed chemical kinetic reaction mechanism used in these calculations was based on the hierarchical nature of reacting systems starting with a core mechanism describing $\mathrm{H}_{2} / \mathrm{O}_{2}$ and $\mathrm{CO}$ oxidation. To this is added the progressively larger $C_{1}-C_{2}$ mechanism and ultimately the DME mechanism whereby the complete model consists of 78 different chemical species and 336 elementary reactions.

The thermodynamic properties for the relevant radicals and stable parents were obtained by group additivity using THERM [18] with updated H/C/O groups and bond dissociation groups [19]. The thermochemical data, listed in Table 1, allow the calculation of reverse reaction rate constants by microscopic reversibility. The dimethyl ether reaction submechanism is listed in table 2 while a full listing of the reaction mechanism can be obtained by Internet electronic mail (curran6@llnl.gov) or on disk or print by writing to the authors.

\section{Dimethyl Ether Oxidation}

The overall reaction scheme for DME oxidation can be depicted as follows:

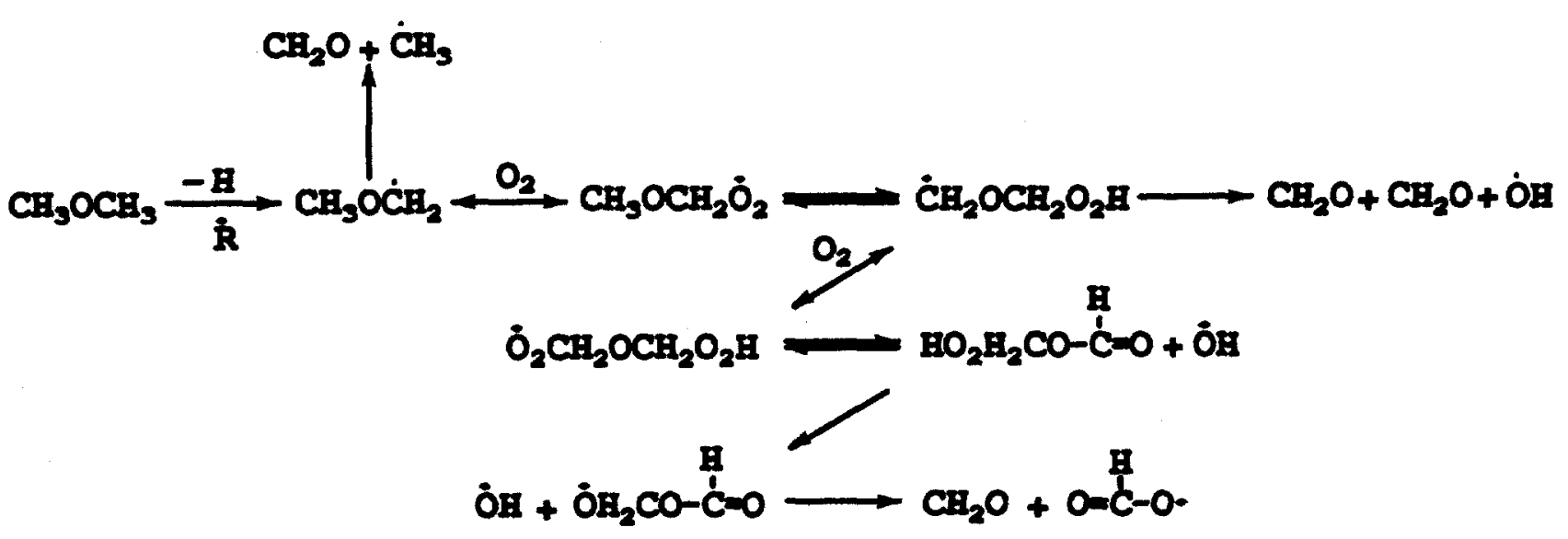

Figure 1: Overall reaction scheme for dimethyl ether oxidation 
where $\dot{\mathrm{R}}$ refers to an arbitrary radical such as $\dot{\mathrm{C}} \mathrm{H}_{3}, \mathrm{CH}_{3} \dot{\mathrm{O}}, \dot{\mathrm{O}} \mathrm{H}$, and $\dot{\mathrm{H}}$ atom. We define species names as follows: $\mathrm{CH}_{3} \mathrm{OCH}_{3}$ (dimethyl ether), $\mathrm{CH}_{3} \mathrm{OCH}_{2}$ (methoxy-methyl radical), $\mathrm{CH}_{3} \mathrm{OCH}_{2} \dot{\mathrm{O}}_{2}$ (methoxy-methylperoxy), $\dot{\mathrm{CH}}_{2} \mathrm{OCH}_{2} \mathrm{O}_{2} \mathrm{H}$ (hydroperoxy-methoxy-methyl), $\dot{\mathrm{O}}_{2} \mathrm{CH}_{2} \mathrm{OCH}_{2} \mathrm{O}_{2} \mathrm{H}$ (peroxy-methoxy methylhydroperoxide radical) and $\mathrm{HO}_{2} \mathrm{CH}_{2} \mathrm{OCHO}$ (hydroperoxy-methylformate).

At high temperatures, the fuel consumption pathway is quite simple, with unimolecular fuel decomposition, (reaction 313), forming methoxy and methyl radicals, and $\beta$-scission of the methoxy-methyl radical (reaction 322) proceeding to formaldehyde and methyl radical.

However, at low temperatures, chain branching is due primarily to the reaction pathway leading through the ketohydroperoxide species. As the temperature increases through the negative temperature coefficient region, the chain propagation reactions of alkylhydroperoxide species increase in importance, leading to the formation of $\beta$-decomposition products, while the proportion of chain branching reactions decrease. The present study was carried out over a broad range of temperature (650-1300 K), where both low and high temperature chemistry contribute to fuel oxidation.

\section{Unimolecular fuel decomposition}

In this study, initiation occurs via the following two reactions,

$$
\begin{aligned}
\mathrm{CH}_{3} \mathrm{OCH}_{3} \stackrel{313}{\longrightarrow} \mathrm{CH}_{3} \mathrm{O}+\dot{\mathrm{CH}}_{3} \\
\mathrm{CH}_{3} \mathrm{OCH}_{3}+\mathrm{O}_{2} \stackrel{320}{\longrightarrow} \mathrm{CH}_{3} \mathrm{OC} \dot{C H}_{2}+\mathrm{HO}_{2}
\end{aligned}
$$

The rate constant for unimolecular decomposition of dimethyl ether was estimated using a chemical activation formalism based on Quantum Rice-Ramsperger-Kassel (QRRK) theory, as described by Dean [20]. This analysis used a high pressure limit rate constant for $\mathrm{CH}_{3} \dot{\mathrm{O}}+\dot{\mathrm{C}} \mathrm{H}_{3}$ addition of $5.0 \times 10^{13} \mathrm{~cm}^{3}$ $\mathrm{mol}^{-1} \mathrm{~s}^{-1}$ [21]. The calculated rate constants for unimolecular fuel decomposition are given in Table 2 at pressures of 1,10 and 40 atm. There have been a number of different measurements of this rate constant expression. Pacey [10] measured the rate of unimolecular decomposition to be $1.0 \times 10^{15} \exp (-$ $76.004 \mathrm{kcal} / \mathrm{RT}) \mathrm{s}^{-1}$ in the temperature range $782-936 \mathrm{~K}$, at a pressure of 25-395 torr and with dimethyl ether as the bath gas. Aronowitz and Naegeli [11] measured the rate constant for decompsition to be $2.16 \times 10^{15} \exp (-76.601 \mathrm{kcal} / \mathrm{RT}) \mathrm{s}^{-1}$ at $1 \mathrm{~atm}$. in the temperature range 1063-1223 $\mathrm{K}$ using $\mathrm{N}_{2}$ as the bath gas. Batt et al. [22] measured a rate constant expression of $3.16 \times 10^{16} \exp (-83.001 \mathrm{kcal} / \mathrm{RT}) \mathrm{s}^{-1}$ in the temperature range $680-850 \mathrm{~K}$, in the pressure range $400-800$ torr using $\mathrm{CH}_{4}$ as the bath gas. A NIST database [23] fit to these data yields a rate constant expression of $2.62 \times 10^{16} \exp (-82.210 \mathrm{kcal} / \mathrm{RT}) \mathrm{s}^{-1}$ in the temperature range $680-1223 \mathrm{~K}$ and 25-800 torr. This corresponds to a rate constant of $2.815 \times 10^{-2} \mathrm{~s}^{-1}$ at $1 \mathrm{~atm}$. and $1000 \mathrm{~K}$ which is very similar to the value of $2.934 \times 10^{-2} \mathrm{~s}^{-1}$ given by our QRRK fit, at the same temperature and pressure.

\section{$H$ atom abstraction from the fuel}

As the radical pool becomes established, $\mathrm{H}$ atom abstraction from the fuel becomes more important, with abstraction primarily by $\dot{\mathrm{O}}, \dot{\mathrm{H}}, \mathrm{HO}_{2}, \dot{\mathrm{C}} \mathrm{H}_{3}$ and $\mathrm{CH}_{3} \dot{\mathrm{O}}_{2}$ radicals and molecular oxygen, $\mathrm{O}_{2}$, and to a lesser extent by $\mathrm{CH}_{3} \dot{\mathrm{O}}$, and $\dot{\mathrm{O}}$ radicals. The rate constants we use for these abstraction reactions are reported in Table 2.

There have been a number of studies on the rate of $\mathrm{H}$ atom abstraction from dimethyl ether by $\mathrm{OH}$ radicals [24]-[27] in the temperature range $240-440 \mathrm{~K}$, and at pressures from 5-760 torr. However, the temperature range of these measurements is significantly lower than the conditions of the current analysis. In addition, there is some scatter in the measured rate constant expressions and so we have decided to base our rate constant on that measured by Droege and Tully [28] for secondary $\mathrm{H}$ atom abstraction from propane. The bond dissociation energy (BDE) for $\mathrm{H}$ atom abstraction from $\mathrm{CH}_{3} \mathrm{OCH}_{3}$ is $97.5 \mathrm{kcal}^{\mathrm{mol}} \mathrm{m}^{-1}$ which is similar to the value for secondary $\mathrm{H}$ atom abstraction of $98.45 \mathrm{kcal} \mathrm{mol}^{-1}$. There are six $\mathrm{H}$ atoms in the DME molecule and only two secondary $\mathrm{H}$ atoms in propane and so the $\mathcal{A}$-factor has been multiplied 
by three. Most recently, Arif et al. [29] have measured this rate constant expression in the temperature range $295-650 \mathrm{~K}$ and at a pressure of 740 torr. Our rate constant expression is in very good agreement with that measured by Arif et al. and differs by $15 \%$ at $300 \mathrm{~K}, 1.3 \%$ at $400 \mathrm{~K}$ and $11 \%$ at $800 \mathrm{~K}$.

$\mathrm{H}$ atom abstraction from DME by $\dot{\mathrm{H}}$ atoms has been measured by Meagher et al. [30] who report a rate constant expression of $1.30 \times 10^{13} \exp (-4.600 \mathrm{kcal} / \mathrm{RT}) \mathrm{cm}^{3} \mathrm{~mol}^{-1} \mathrm{~s}^{-1}$ in the temperature range 300-404 K, at a pressure of 0.4-0.9 torr with helium as the bath gas. Faubel et al. [31] measured this rate constant also using helium as the bath gas, in the temperature range $250-620 \mathrm{~K}$ and at a pressure of 2.25-9.75 torr and reported a rate constant of $1.90 \times 10^{13} \exp (-5.167 \mathrm{kcal} / \mathrm{RT}) \mathrm{cm}^{3} \mathrm{~mol}^{-1} \mathrm{~s}^{-1}$. Lee et al. [32] published a rate constant expression of $2.64 \times 10^{12} \exp (-3.887 \mathrm{kcal} / \mathrm{RT}) \mathrm{cm}^{3} \mathrm{~mol}^{-1} \mathrm{~s}^{-1}$ in the temperature range $273-426 \mathrm{~K}$, at a pressure of 30-200 torr with argon as the bath gas. The above rate constant expressions have been correlated, together with the rate expression derived by Aronowitz and Naegeli [11] of $1.10 \times 10^{13} \mathrm{~cm}^{3} \mathrm{~mol}^{-1} \mathrm{~s}^{-1}$ in the temperature range 1063-1223 $\mathrm{K}$ and 1 atm. pressure, using the NIST database to generate a three parameter fit to this reaction which is given in Table 2.

Abstraction of $\mathrm{H}$ atom by $\mathrm{HO}_{2}$ and $\mathrm{CH}_{3} \dot{\mathrm{O}}_{2}$ radicals is quite important in the oxidation process. However, these rate constant expressions have not been measured, and therefore there is some degree of uncertainty in their absolute values. Walker [33] recommends a rate constant expression of $2.80 \times 10^{12} \exp (-17.686$ kcal/RT) $\mathrm{cm}^{3} \mathrm{~mol}^{-1} \mathrm{~s}^{-1}$ per $\mathrm{H}$ atom for the abstraction of secondary $\mathrm{H}$ atoms from an alkane by $\mathrm{HO}_{2}$ radicals. We have used this rate expression in our study but with an $\mathcal{A}$-factor of $1.0 \times 10^{13}$ and not $1.68 \times 10^{13}$ using a degeneracy of six. The reduced $\mathcal{A}$-factor gave better agreement with experimental results. In addition, $\mathrm{H}$ atom abstraction from $\mathrm{CH}_{3} \mathrm{OCH}_{3}$ by $\mathrm{CH}_{3} \dot{\mathrm{O}}_{2}$ and $\mathrm{CH}_{3} \mathrm{OCH}_{2} \dot{\mathrm{O}}_{2}$ was taken to equal that by $\mathrm{HO}_{2}$ radicals.

$\mathrm{H}$ atom abstraction by $\dot{\mathrm{CH}}_{3}$ was measured by Pacey [10] who reported a rate constant of $3.16 \times 10^{13} \exp (-$ $15.057 \mathrm{kcal} / \mathrm{RT}$ ) $\mathrm{cm}^{3} \mathrm{~mol}^{-1} \mathrm{~g}^{-1}$ under identical conditions to those given above for his expression for unimolecular fuel decomposition. Batt et al. [22] have also made direct measurements of this rate constant reporting an expression of $3.55 \times 10^{12} \exp (-11.800 \mathrm{kcal} / \mathrm{RT}) \mathrm{cm}^{3} \mathrm{~mol}^{-1} \mathrm{~s}^{-1}$ over the temperature range 373-935 $\mathrm{K}$ and $400-800$ torr pressure with $\mathrm{CH}_{3} \mathrm{OCH}_{3}$ as the bath gas. Other relative measurements by Gray and Herod [34, 35] and Held et al. [12] contributed to a NIST database fit yielding the three parameter rate constant expression reported in Table 2.

Abstraction of $\mathrm{H}$ atoms by $\mathrm{CH}_{3} \mathrm{O}$ radical is taken from twice Tsang's [36] recommendation for $\mathrm{CH}_{3} \mathrm{OH}+$ $\mathrm{CH}_{3} \dot{\mathrm{O}}=\dot{\mathrm{C}} \mathrm{H}_{2} \mathrm{OH}+\mathrm{CH}_{3} \mathrm{OH}$. $\mathrm{H}$ atom abstraction by $\dot{\mathrm{O}}$ atoms has been measured by LeFevre et al. [37] from 1.4-4.1 torr pressure and in the temperature range $217-366 \mathrm{~K}$ with helium bath gas, resulting in the rate constant expression of $5.0 \times 10^{12} \exp (-2.850 \mathrm{kcal} / \mathrm{RT}) \mathrm{cm}^{3} \mathrm{~mol}^{-1} \mathrm{~s}^{-1}$. Faubel et al. [38] measured a rate constant expression of $2.30 \times 10^{10} \mathrm{~cm}^{3} \mathrm{~mol}^{-1} \mathrm{~s}^{-1}$ at $298 \mathrm{~K}$ in the pressure range 2.25-6.76 torr with helium bath gas. Liu et al. [39] measured this rate expression to be $3.24 \times 10^{12} \exp (-2.623 \mathrm{kcal} / \mathrm{RT}) \mathrm{cm}^{3} \mathrm{~mol}^{-1} \mathrm{~s}^{-1}$ in the temperature range $240-400 \mathrm{~K}$ and 25-50 torr pressure, using argon bath gas. Herron [40] carried out an extensive literature review of this rate constant and recommends an expression of $5.0 \times 10^{13} \exp (-4.571$ $\mathrm{kcal} / \mathrm{RT}$ ) $\mathrm{cm}^{3} \mathrm{~mol}^{-1} \mathrm{~s}^{-1}$ in the temperature range 300-500 K. We have performed a NIST database fit to the above recommendations and report a three parameter fit to this data in Table 2.

\section{Reactions of methoxy-methyl radical}

Methoxy-methyl radicals can undergo two different reaction:

- addition to molecular oxygen to produce methoxy methyl-peroxy radicals, $\mathrm{CH}_{3} \mathrm{OCH}_{2} \dot{\mathrm{O}}_{2}$.

- $\beta$-scission to yield formaldehyde and methyl radicals.

Addition to $\mathrm{O}_{2}$ mainly occurs at low temperatures as the activation energy barrier to $\beta$-scission products is $25.500 \mathrm{kcal} \mathrm{mol}^{-1}$ while the bimolecular addition of methoxy-methyl radical to $\mathrm{O}_{2}$ has no activation energy barrier associated with it. The $\mathcal{A}$-factor for addition to $O_{2}$ was taken to be $1.0 \times 10^{12} \mathrm{~cm}^{3} \mathrm{~mol}^{-1} \mathrm{~s}^{-1}$ similar to that recommended by Benson [41] for the addition of alkyl radicals to molecular oxygen. The rate of 
$\mathrm{CH}_{3} \mathrm{OCH}_{2} \beta$-8cission (reaction 322), was taken from the study of Loucks and Laidler [42] which reported a high-pressure limit Arrhenius expression in the temperature range 373-473 K, Table 2.

\section{Reactions of methoxy methyl-peroxy radical}

The $\mathrm{CH}_{3} \mathrm{OCH}_{2} \mathrm{O}_{2}$ radical which occurs at low temperature (500 $\left.\leq T \leq 900 \mathrm{~K}\right)$ can undergo three different types of reaction:

1. Decomposition to $\mathrm{CH}_{3} \mathrm{O} \dot{\mathrm{C}} \mathrm{H}_{2}+\mathrm{O}_{2}$. This rate constant is calculated from the reverse rate constant and from microscopic reversibility (thermochemistry).

2. Intermolecular abstraction of hydrogen atoms from other hydrocarbon species to produce the stable methoxy-methylhydroperoxide species, $\left(\mathrm{CH}_{3} \mathrm{OCH}_{2} \mathrm{O}_{2} \mathrm{H}\right)$, which then decomposes to $\mathrm{CH}_{3} \mathrm{OCH}_{2} \mathrm{O}+$ $\mathrm{OH}$, followed by reactions of the $\mathrm{CH}_{3} \mathrm{OCH}_{2} \mathrm{O}$ radical. Modeling results showed this sequence of reactions to be of relatively minor importance in this study.

3. The most important step involves isomerization of the $\mathrm{CH}_{3} \mathrm{OCH}_{2} \mathrm{O}_{2}$ radical via internal $\mathrm{H}$ atom transfer to form hydroperoxy-methoxy methyl radical, $\mathrm{CH}_{2} \mathrm{OCH}_{2} \mathrm{O}_{2} \mathrm{H}$. The rate constant for isomerization is described in terms of the number of atoms in the transition state ring structure, which includes the $\mathrm{H}$ atom, and the type of site (primary in this case) at which the transferred $\mathrm{H}$ atom is initially located. Thus, we estimate the activation energy, $\mathcal{E}_{a}$, using the expression,

$$
\mathcal{E}_{a}=\Delta H_{\text {rxn }}+\text { ring strain }+E_{\text {abst }}
$$

where $\Delta H_{\text {rxn }}$ is taken to be the enthalpy of reaction and is included only if the reaction is endothermic. The activation energy for abstraction is determined, following the analysis of Bozzelli and Pitz [43], from an Evans-Polanyi plot ( $\mathrm{E}_{\mathrm{abst}}$ vs $\Delta H_{\mathrm{rxn}}$ ) of similar $\mathrm{H}$ atom abstraction reactions, $\mathrm{RH}+\dot{\mathrm{R}}^{\prime}=\mathrm{R}^{\prime}$ $+R^{\prime} H$ leading to the following expression:

$$
E_{\text {abst }}=12.7+\left(\Delta H_{\text {rxn }} \times 0.37\right)
$$

As this transition state involves a six membered ring we assume there is no ring strain. In addition, from thermochemistry (Table 1) we find $\Delta H_{\text {rxn }}=+9.30 \mathrm{kcal} \mathrm{mol}^{-1}$ and therefore $\mathcal{E}_{a}=$ $18.560 \mathrm{kcal} \mathrm{mol}{ }^{-1}$. The $\mathcal{A}$-factor was chosen to be $7.42 \times 10^{11} \mathrm{~s}^{-1}$, identical to that used for a $(1,5)$ transition state ring in our modeling of n-heptane oxidation [44]. The reverse isomerization rate constant is based on the forward rate constant and on calculated thermodynamic properties using bond additivity.

\section{Reactions of $\dot{\mathrm{CH}}_{2} \mathrm{OCH}_{2} \mathrm{O}_{2} \mathrm{H}$.}

The hydroperoxy-methoxy methyl species formed can react via three major pathways.

1. Reverse isomerization of $\dot{\mathrm{C}} \mathrm{H}_{2} \mathrm{OCH}_{2} \mathrm{O}_{2} \mathrm{H}$ radical to $\mathrm{CH}_{3} \mathrm{OCH}_{2} \dot{\mathrm{O}}_{2}$ radical as described above.

2. The $\dot{\mathrm{C}} \mathrm{H}_{2} \mathrm{OCH}_{2} \mathrm{O}_{2} \mathrm{H}$ species can undergo $\beta$-scission, leading to the formation of two molecules of formaldehyde and $\mathrm{OH}$ radical, as the hydroperoxy-methyl radical $\left(\mathrm{CH}_{2} \mathrm{O}_{2} \mathrm{H}\right)$ is assumed to decompose into formaldehyde and $\dot{O} H$ radical very quickly. This endothermic rate constant is unknown but was estimated as follows. The reverse rate (i.e. addition of hydroperoxy-methyl radical to formaldehyde) was likened to a methyl radical adding across the double bond in ethylene to yield the $\mathrm{nC}_{3} \mathrm{H}_{7}$ radical. The rate for this reaction was taken from Baulch et al. [45] to be $2.11 \times 10^{11}$ exp $(-7.40$ $\mathrm{kcal} / \mathrm{RT}$ ) $\mathrm{cm}^{3} \mathrm{~mol}^{-1} \mathrm{~s}^{-1}$. The forward rate constant was then calculated by microscopic reversibility. This gives a rate constant expression in the forward direction of $1.25 \times 10^{13} \exp (-21.160$ kcal/RT) $\mathrm{cm}^{3} \mathrm{~mol}^{-1} \mathrm{~s}^{-1}$. However, it was found that it was necessary to adjust the calculated forward activation energy downward by $3.0 \mathrm{kcal} \mathrm{mol} \mathrm{m}^{-1}$ in order to predict the ignition delay times 
measured by Pfahl and co-workers [16]; in particular, to simulate the point at which the NTC region comes into effect. It is reasoned that the presence of the 0 atom in formaldehyde reduces the activation energy of the addition of $\dot{\mathrm{CH}}_{2} \mathrm{O}_{2} \mathrm{H}$ to the double bond. The final rate expression is shown in Table 2.

3. In addition, hydroperoxy-methyl methoxy species can react with molecular oxygen to form the $\dot{\mathrm{O}}_{2} \mathrm{CH}_{2} \mathrm{OCH}_{2} \mathrm{O}_{2} \mathrm{H}$ radical. The rate of this reaction was taken to be $9.0 \times 10^{11} \mathrm{~cm}^{3} \mathrm{~mol}^{-1} \mathrm{~s}^{-1}$, just slightly less than that used for the addition of methoxy-methyl radical to $\mathrm{O}_{2}$.

\section{$\dot{\mathrm{O}}_{2} \mathrm{CH}_{2} \mathrm{OCH}_{2} \mathrm{O}_{2} \mathrm{H}$ isomerization}

It is important to note that the fate of the $\mathrm{CH}_{2} \mathrm{OCH}_{2} \mathrm{O}_{2} \mathrm{H}$ radical determines the reactivity of the system at low temperatures; the faster the rate of $\beta$-scission of $\mathrm{CH}_{2} \mathrm{OCH}_{2} \mathrm{O}_{2} \mathrm{H}$ radical leads to reduced reactivity, while addition to $\mathrm{O}_{2}$ leads to chain branching and hence greater reactivity. The $\mathrm{O}_{2} \mathrm{CH}_{2} \mathrm{OCH}_{2} \mathrm{O}_{2} \mathrm{H}$ radical isomerizes, releasing $\mathrm{OH}$ and producing a stable ketohydroperoxide molecule, $\mathrm{HO}_{2} \mathrm{CH}_{2} \mathrm{OCHO}$, Figure 1 . The rate for this isomerization via an internal $\mathrm{H}$ atom transfer, presented in Table 2, is calculated in identical manner to that for $\mathrm{CH}_{3} \mathrm{OCH}_{2} \dot{\mathrm{O}}_{2} \rightleftharpoons \dot{\mathrm{CH}_{2}} \mathrm{OCH}_{2} \mathrm{O}_{2} \mathrm{H}$ isomerization. The activation energy has been calculated to be $16.30 \mathrm{kcal} \mathrm{mol}^{-1}$ and the $\mathcal{A}$-factor has been reduced by a factor of 0.5 considering steric hindrance due to the $\mathrm{OOH}$ group.

\section{Ketohydroperoxide decomposition}

Finally, the decomposition of the ketohydroperoxide molecule leads to chain branching, as two radicals are formed from its decomposition, $\mathrm{OH}$ and $\mathrm{OCH}_{2} \mathrm{OCHO}$ radicals. The rate constant of $2.0 \times 10^{13} \mathrm{~cm}^{3} \mathrm{~mol}^{-1}$ $\mathrm{s}^{-1}$ was chosen is the reverse direction, the addition of $\dot{\mathrm{OH}}$ radical to $\mathrm{OCH}_{2} \mathrm{OCHO}$ and the forward rate constant was determined from microscopic reversibility. This resulted in a three parameter rate constant expression in the forward direction with an activation energy of $47.090 \mathrm{kcal} \mathrm{mol}^{-1}$. It was necessary to reduce this activation energy by $3.0 \mathrm{kcal} \mathrm{mol}^{-1}$ in order to reproduce the experimental data at low temperatures.

The $\mathrm{OCH}_{2} \mathrm{OCHO}$ radical decomposes to produce formaldehyde and $\mathrm{HCO}_{2}$ radical. The rate constant of this reaction was considered in the reverse direction addition of $\mathrm{HCO}_{2}$ radical to $\mathrm{CH}_{2} \mathrm{O}$. The reverse rate constant was estimated to be $1.25 \times 10^{11} \exp (-7.40 \mathrm{kcal} / \mathrm{RT}) \mathrm{cm}^{3} \mathrm{~mol}^{-1} \mathrm{~s}^{-1}$ and the forward rate constant, reported in Table 2 was determined from thermochemistry.

\section{Jet-Stirred Reactor Results}

In this section, the product species concentrations calculated by the model and measured in the JSR experiments [15] are discussed and compared. The JSR experiments are a stringent test of the high temperature portion of the model, as they test the detailed distribution of both primary and secondary product formation. Comparisons of the product species profiles measured in the experiment and calculated in the model simulation are shown in Figures 2-6 for mixtures varying from fuel lean to fuel rich. It is clear that the model predicted concentration profiles for each product species are in good agreement with the experimental results. The computational fuel concentration profiles are also in good agreement for all mixtures. However, at $0.2 \% \mathrm{DME}, \phi=2.5$ and $10 \mathrm{~atm}$ pressure the model underpredicts the rate of $\mathrm{O}_{2}$ consumption. However, fuel consumption is accurately predicted.

\section{Product Formation}

Under stoichiometric conditions, $\phi=1.0$, the primary products formed are carbon monoxide (CO), hydrogen $\left(\mathrm{H}_{2}\right)$, methane $\left(\mathrm{CH}_{4}\right)$, formaldehyde $\left(\mathrm{CH}_{2} \mathrm{O}\right)$ and carbon dioxide $\left(\mathrm{CO}_{2}\right)$, Figures 2-4. It can be seen that the model is able to reproduce the fuel, $\mathrm{O}_{2}$ and product profiles observed in the experiment, although the model underpredicts the measured concentration profile for ethene at 10 atm and $\phi=1.3$ by about a factor of two. Product formation can be fully explained by the reaction scheme discussed below. 
The radical pool is initiated by unimolecular decomposition:

$$
\mathrm{CH}_{3} \mathrm{OCH}_{3} \stackrel{313}{\longrightarrow} \mathrm{CH}_{3} \dot{\mathrm{O}}+\dot{\mathrm{C}} \mathrm{H}_{3}
$$

which leads to the formation of methoxy, $\mathrm{CH}_{3} \dot{\mathrm{O}}$ and methyl, $\dot{\mathrm{C}} \mathrm{H}_{3}$ radicals. Methoxy radicals can decompose to form formaldehyde and $\mathrm{H}$ atoms, while $\mathrm{H}$ atoms, via reaction 315 , and $\dot{\mathrm{CH}}_{3}$ radicals, via reaction 319 , abstract $\mathrm{H}$ atoms from the fuel to produce methoxy-methyl radical and hydrogen and methane respectively.

$$
\begin{array}{rll}
\mathrm{CH}_{3} \dot{\mathrm{O}} & \stackrel{40}{\longrightarrow} \mathrm{CH}_{2} \mathrm{O}+\dot{\mathrm{H}} \\
\mathrm{CH}_{3} \mathrm{OCH}_{3}+\dot{\mathrm{H}} & \stackrel{315}{\longrightarrow} \mathrm{CH}_{3} \mathrm{O} \dot{\mathrm{CH}} \mathrm{H}_{2}+\mathrm{H}_{2} \\
\mathrm{CH}_{3} \mathrm{OCH}_{3}+\dot{\mathrm{CH}} \mathrm{H}_{3} & \stackrel{319}{\longrightarrow} \mathrm{CH}_{3} \mathrm{O} \dot{\mathrm{C}} \mathrm{H}_{2}+\mathrm{CH}_{4}
\end{array}
$$

Subsequent $\beta$-scission of the methoxy-methyl radical also leads to the formation of formaldehyde and methyl radical (reaction 322), which is the predominant route to $\mathrm{CH}_{2} \mathrm{O}$ formation as the radical pool becomes more established. Furthermore, as the radical pool concentration increases, $\dot{\mathrm{CH}}_{3}$ reacts with $\mathrm{HO}_{2}$ radical to produce $\mathrm{CH}_{3} \dot{\mathrm{O}}+\dot{\mathrm{O}} \mathrm{H}$, further promoting formaldehyde formation and producing reactive hydroxyl radical that abstract $\mathrm{H}$ atoms from the fuel.

$$
\begin{array}{rll}
\mathrm{CH}_{3} \mathrm{OC} \mathrm{CH}_{2} & \stackrel{322}{\longrightarrow} \mathrm{CH}_{2} \mathrm{O}+\dot{\mathrm{C}} \mathrm{H}_{3} \\
\dot{\mathrm{CH}}_{3}+\mathrm{HO}_{2} & \stackrel{22}{\longrightarrow} \mathrm{CH}_{3} \mathrm{O}+\dot{\mathrm{OH}} \\
\mathrm{CH}_{3} \mathrm{OCH}_{3}+\dot{\mathrm{OH}} & \stackrel{314}{\longrightarrow} \mathrm{CH}_{3} \mathrm{OC} \mathrm{CH}_{2}+\mathrm{H}_{2} \mathrm{O}
\end{array}
$$

Methyl radical reacts with formaldehyde, molecular hydrogen, fuel, and $\mathrm{HO}_{2}$ to yield methane and a radical species.

$$
\begin{aligned}
\mathrm{CH}_{2} \mathrm{O}+\dot{\mathrm{CH}}_{3} & \stackrel{38}{\longrightarrow} \mathrm{HCO}+\mathrm{CH}_{4} \\
\dot{\mathrm{C}} \mathrm{H}_{3}+\mathrm{H}_{2} & \stackrel{-2}{\longrightarrow} \mathrm{CH}_{4}+\dot{\mathrm{H}} \\
\dot{\mathrm{C}} \mathrm{H}_{3}+\mathrm{HO}_{2} & \stackrel{45}{\longrightarrow} \mathrm{CH}_{4}+\mathrm{O}_{2}
\end{aligned}
$$

$\mathrm{H}$ atoms, which lead to the formation of molecular hydrogen, are generated from the decomposition of both formyl, $\mathrm{HC} O$ (reaction 12), and methoxy radicals, $\mathrm{CH}_{3} \dot{\mathrm{O}}$ (reaction 40) above. Reaction 12 also leads to the formation of carbon monoxide which reacts with $\mathrm{HO}_{2}$ radical and to a lesser extend with $\dot{\mathrm{OH}}$ radical to form carbon dioxide and $\dot{O} H$ and $\dot{\mathrm{H}}$ radicals respectively.

$$
\begin{aligned}
\mathrm{HCO} & \stackrel{12}{\longrightarrow} \dot{\mathrm{H}}+\mathrm{CO} \\
\mathrm{CO}+\mathrm{HO}_{2} & \stackrel{23}{\longrightarrow} \mathrm{CO}_{2}+\dot{\mathrm{O}} \mathrm{H} \\
\mathrm{CO}+\dot{\mathrm{O}} \mathrm{H} & \stackrel{7}{\longrightarrow} \mathrm{CO}_{2}+\dot{\mathrm{H}}
\end{aligned}
$$

Under fuel lean conditions, less $\mathrm{H}_{2}$ and $\mathrm{CH}_{4}$ and more $\mathrm{CO}$ and $\mathrm{CO}_{2}$ are formed relative to the stoichiometric case. This is because the higher concentration of $\mathrm{O}_{2}$ results in more $\mathrm{HO}_{2}$ formation and this radical reacts with methyl radicals forming methoxy and $\mathrm{OH}$ radicals (reaction 22) above. The methoxy radical decomposes to formaldehyde which subsequently yields $\mathrm{CO}$ and then $\mathrm{CO}_{2}$. Under fuel rich conditions the 
reverse is true, higher concentrations of $\mathrm{H}_{2}$ and $\mathrm{CH}_{4}$ are formed due to the reduced concentration of $\mathrm{HO}_{2}$ radicals.

The formation of ethane, $\mathrm{C}_{2} \mathrm{H}_{6}$, is explained by the recombination of $\dot{\mathrm{C}} \mathrm{H}_{3}$ radicals (reaction 24). The rate constant expression for this reaction was taken from the work of Walter et al. [46] which includes a Troe fall-off fit to this reaction.

$$
\mathrm{C}_{2} \mathrm{H}_{6}+(\mathrm{M}) \stackrel{24}{\longrightarrow} \dot{\mathrm{C}} \mathrm{H}_{3}+\dot{\mathrm{CH}}_{3}+(\mathrm{M})
$$

Ethane subsequently undergoes $\mathrm{H}$ atom abstraction by $\dot{\mathrm{H}}, \dot{\mathrm{O}} \mathrm{H}$ and $\dot{\mathrm{C}} \mathrm{H}_{3}$, forming ethyl radical, $\dot{\mathrm{C}}_{2} \mathrm{H}_{5}$, which decomposes to ethene, $\mathrm{C}_{2} \mathrm{H}_{4}$ and $\mathrm{H}$ atom.

$$
\begin{aligned}
& \mathrm{C}_{2} \mathrm{H}_{6}+\dot{\mathrm{R}} \longrightarrow \dot{\mathrm{C}}_{2} \mathrm{H}_{5}+\mathrm{RH} \\
& \mathrm{C}_{2} \mathrm{H}_{5}+\mathrm{M} \stackrel{15}{\longrightarrow} \mathrm{C}_{2} \mathrm{H}_{4}+\dot{\mathrm{H}}
\end{aligned}
$$

Ethene subsequently undergoes $\mathrm{H}$ atom abstraction by $\dot{\mathrm{H}}, \dot{\mathrm{O}} \mathrm{H}$ and $\dot{\mathrm{C}} \mathrm{H}_{3}$, forming vinyl radical, $\dot{\mathrm{C}}_{2} \mathrm{H}_{3}$, which reacts with $\mathrm{O}_{2}$ to form formaldehyde and formyl radical, and to a lesser extent, ethyne $\left(\mathrm{C}_{2} \mathrm{H}_{2}\right)$, and $\mathrm{HO}_{2}$ radical.

$$
\begin{gathered}
\mathrm{C}_{2} \mathrm{H}_{4}+\dot{\mathrm{R}} \longrightarrow \dot{\mathrm{C}}_{2} \mathrm{H}_{3}+\mathrm{RH} \\
\dot{\mathrm{C}}_{2} \mathrm{H}_{3}+\mathrm{O}_{2} \stackrel{112}{\longrightarrow} \mathrm{CH}_{2} \mathrm{O}+\mathrm{HC} \mathrm{O} \\
\dot{\mathrm{C}}_{2} \mathrm{H}_{3}+\mathrm{O}_{2} \stackrel{85}{\longrightarrow} \mathrm{C}_{2} \mathrm{H}_{2}+\mathrm{HO}_{2}
\end{gathered}
$$

\section{Shock Tube Results}

The low temperature portion of the chemical kinetic mechanism, which is depicted in Figure 1, and described earlier with the associated rate constant expressions, Table 2, and the high temperature mechanism was used to model the experimental results of $\mathrm{Pfahl}$ et al. [16] in a high pressure shock tube. A comparison of model prediction with the experimental results can be seen in Figure 7, and indicates that the model is able to predict accurately the total ignition delay times measured in the experiments. Furthermore, the model accurately predicts the experimentally measured first stage ignition delay times $\left(\tau_{1}\right)$, at 40 bar, but predicts a longer first stage ignition time at 13 bar.

At low temperatures $\left(\mathrm{T}<1100 \mathrm{~K}\right.$ ) the methoxy-methyl radical adds with $\mathrm{O}_{2}$ leading to the formation of the hydroperoxy-alkyl, $\mathrm{CH}_{2} \mathrm{OCH}_{2} \mathrm{O}_{2} \mathrm{H}$ radical, Figure 1 . At temperatures below $800 \mathrm{~K}$ molecular oxygen adds to this molecule resulting in the formation of the stable ketohydroperoxide molecule, which decomposes leading to chain branching and fast fuel ignition. However, as the temperature rises above $800 \mathrm{~K}$, the $\dot{\mathrm{C}} \mathrm{H}_{2} \mathrm{OCH}_{2} \mathrm{O}_{2} \mathrm{H}$ radical starts to undergo $\beta$-scission which yields two formaldehyde molecules and $\dot{\mathrm{OH}}$ radical, and thus is a propagation process. This results in the NTC behaviour observed in both the experiments and the model predictions, Figure 7. At temperatures above $1100 \mathrm{~K}$, high temperature kinetics control fuel oxidation and the alkyl radical, $\mathrm{CH}_{3} \mathrm{OC}_{2} \mathrm{H}_{2}$ no longer undergoes addition to $\mathrm{O}_{2}$ but decomposes via $\beta$-scission to form methyl radical and formaldehyde.

\section{Sensitivity Analysis}

In analysing the chemistry edits produced as output from the HCT code, we were able to develop a flux diagram of the major oxidation pathways responsible for DME oxidation, Figure 1. Therefore, we have carried out a detailed sensitivity analysis focusing on these reactions, but also included additional reactions 
such as $\dot{\mathrm{C}} \mathrm{H}_{3}+\mathrm{HO}_{2}=\mathrm{CH}_{3} \dot{\mathrm{O}}+\dot{\mathrm{O}} \mathrm{H}$, and $\dot{\mathrm{H}}+\mathrm{O}_{2}+\mathrm{M}=\mathrm{HO}_{2}+\mathrm{M}$ as these reactions were shown above to influence the coxidation of DME in the JSR experiments.

The sensitivity analysis was performed by multiplying the rate constant of a reaction by a factor of two (both forward and reverse rate constants) and then calculating the percent change in reactivity. Therefore, in the case of the shock tube experiments of Pfahl et al. [16] we calculated the percent change in ignition delay time compared with the baseline simulation. A positive percent change indicates a decreased overall reaction rate and a negative change an increased overall reactivity of the system. Three different temperatures were chosen to help indicate sensitivity of each class to the onset, middle and end of the NTC region at an average pressure of $40 \mathrm{~atm}$. The reaction rate constants that exhibited the highest sensitivity are shown in Figure 8.

At low temperatures the reactions with greatest negative sensitivity and hence is the most effective in promoting the overall rate of oxidation are $\mathrm{H}$ atom abstractions from the fuel by $\dot{\mathrm{O}}, \mathrm{HO}_{2}$, and $\mathrm{O}_{2}$, and the addition of $\mathrm{CH}_{2} \mathrm{OCH}_{2} \mathrm{O}_{2} \mathrm{H}$ to $\mathrm{O}_{2}$ and subsequent reactions which lead to chain branching. The decomposition of the ketohydroperoxide molecule has the greatest sensitivity at $650 \mathrm{~K}$.

$$
\begin{array}{rll}
\mathrm{CH}_{3} \mathrm{OCH}_{3}+\dot{\mathrm{OH}} & \stackrel{314}{\longrightarrow} \mathrm{CH}_{3} \mathrm{OC} \mathrm{CH}_{2}+\mathrm{H}_{2} \mathrm{O} \\
\mathrm{CH}_{3} \mathrm{OCH}_{3}+\mathrm{HO}_{2} & \stackrel{317}{\longrightarrow} \mathrm{CH}_{3} \mathrm{OC}_{2}+\mathrm{H}_{2} \mathrm{O}_{2} \\
\dot{\mathrm{O}}_{2} \mathrm{CH}_{2} \mathrm{OCH}_{2} \mathrm{O}_{2} \mathrm{H} & \stackrel{335}{\longrightarrow} & \dot{\mathrm{CH}}_{2} \mathrm{OCH}_{2} \mathrm{O}_{2} \mathrm{H}+\mathrm{O}_{2} \\
\dot{\mathrm{O}}_{2} \mathrm{CH}_{2} \mathrm{OCH}_{2} \mathrm{O}_{2} \mathrm{H} & \stackrel{336}{\longrightarrow} & \mathrm{HO}_{2} \mathrm{CH}_{2} \mathrm{OCHO}+\mathrm{OH} \\
\mathrm{HO}_{2} \mathrm{CH}_{2} \mathrm{OCHO} & \stackrel{337}{\rightleftharpoons} & \mathrm{OCH}_{2} \mathrm{OCHO}+\dot{\mathrm{OH}}
\end{array}
$$

At low temperatures isomerization of the $\dot{\mathrm{O}}_{2} \mathrm{CH}_{2} \mathrm{OCH}_{2} \mathrm{O}_{2} \mathrm{H}$ radical (reaction 336), leads to the formation of the ketohydroperoxide molecule, $\mathrm{HO}_{2} \mathrm{CH}_{2} \mathrm{OCHO}+\mathrm{OH}$. Subsequent decomposition of the ketohydroperoxide molecule leads to the formation of another $\dot{O} H$ radical and an oxygenated-alkoxy radical which is chain branching. However, at low temperatures the high activation energy barrier (44070 cal $/ \mathrm{mol}$ ) associated with ketohydroperoxide decomposition is difficult to overcome and ensures that decomposition of the stable ketohydroperoxide species occurs very slowly. As fuel oxidation proceeds and the associated heat release raises the reactor temperature, these stable molecules decompose more readily relieving this "bottleneck" and ensuring greater reactivity of the system. This behaviour is, to large degree, responsible for the first stage or "cool-flame" ignition at low temperatures.

The reaction which is next greatest in promoting the rate of fuel oxidation at $650 \mathrm{~K}$ and shows the highest negative sensitivity coefficient at $850 \mathrm{~K}$ is the addition of the hydroperoxy-alkyl radical to molecular oxygen, $\mathrm{CH}_{2} \mathrm{OCH}_{2} \mathrm{O}_{2} \mathrm{H}+\mathrm{O}_{2}$, (reaction -335), which competes with the $\beta$-scission reaction of $\dot{\mathrm{C}} \mathrm{H}_{2} \mathrm{OCH}_{2} \mathrm{O}_{2} \mathrm{H}$ to form two formaldehyde molecules and $\mathrm{OH}$ radical (reaction 334). The molecular addition to $\mathrm{O}_{2}$ leads to the formation of the ketohydroperoxide molecule and favours chain branching, while the $\beta$-scission reaction has the highest positive sensitivity coefficient at both $650 \mathrm{~K}$ and $850 \mathrm{~K}$ as it competes with the chain branching process, forming only one reactive $\dot{\mathrm{O}} \mathrm{H}$ radical. $\mathrm{H}$ atom abstraction from the fuel by $\dot{\mathrm{O}} \mathrm{H}$, $\dot{\mathrm{H}}, \mathrm{HO}_{2}, \mathrm{CH}_{3} \dot{\mathrm{O}}_{2}$, and $\mathrm{CH}_{3} \dot{\mathrm{O}}$ all show relatively high negative coefficients at a temperature of $850 \mathrm{~K}$ and above, as they help promote fuel consumption. $\mathrm{H}$ atom abstraction by $\mathrm{OH}$ radical has the second highest negative sensitivity at $850 \mathrm{~K}$ as the low temperature chain branching pathways lead to high concentrations of this radical.

One interesting result of the sensitivity analysis is the sensitivity to reaction 318 :

$$
\mathrm{CH}_{3} \mathrm{OCH}_{3}+\mathrm{CH}_{3} \dot{\mathrm{O}}_{2} \stackrel{318}{\longrightarrow} \mathrm{CH}_{3} \mathrm{O} \dot{\mathrm{CH}} \mathrm{H}_{2}+\mathrm{CH}_{3} \mathrm{O}_{2} \mathrm{H}
$$

The sensitivity coefficient pertaining to this reaction increases with rising temperature, Figure 8-9. The 
concentration of methyl radicals steadily increases with temperature rise as methoxy-methyl radical $\beta$ scission becomes more and more important. This allows for higher concentrations of $\mathrm{CH}_{3} \dot{\mathrm{O}}_{2}$ radicals and more $\mathrm{CH}_{3} \mathrm{O}_{2} \mathrm{H}$ molecules. With rising temperatures methylperoxide molecules decompose more readily to produces reactive methoxy and hydroxyl radicals (reaction 191).

$$
\mathrm{CH}_{3} \mathrm{O}_{2} \mathrm{H} \stackrel{191}{\longrightarrow} \mathrm{CH}_{3} \dot{\mathrm{O}}+\dot{\mathrm{OH}}
$$

This sequence of reactions consumes $\mathrm{O}_{2}$ and the relatively unreactive $\dot{\mathrm{C}} \mathrm{H}_{3}$ radical, producing two more reactive radicals in return, an $\dot{\mathrm{O}} \mathrm{H}$ radical and a $\mathrm{CH}_{3} \dot{\mathrm{O}}$ radical, which can decompose to yield formaldehyde and reactive $\mathrm{H}$ atom or abstract a $\mathrm{H}$ atom directly from the fuel.

Another reaction that exhibits similar behaviour is the reaction of methyl radicals with hydroperoxyl radical (reaction 22):

$$
\dot{\mathrm{C}} \mathrm{H}_{3}+\mathrm{HO}_{2} \stackrel{22}{\longrightarrow} \mathrm{CH}_{3} \dot{\mathrm{O}}+\dot{\mathrm{O}} \mathrm{H}
$$

Again, this reaction leads to the formation of $\mathrm{CH}_{3} \dot{\mathrm{O}}$ and $\dot{\mathrm{O}} \mathrm{H}$ radicals. Note that the sensitivity coefficient for $\mathrm{H}$ atom abstraction by $\mathrm{CH}_{3} \dot{\mathrm{O}}_{2}$ from the fuel and $\dot{\mathrm{CH}}_{3}+\mathrm{HO}_{2}$ (reaction 22), are greater than that for $\mathrm{H}$ atom abstraction by $\dot{\mathrm{O}} \mathrm{H}$ radicals. This is because at $1000 \mathrm{~K} \beta$-scission of the methoxy-methyl radical has becomes more important than $\mathrm{O}_{2}$ addition, thus producing higher concentrations of $\dot{\mathrm{CH}}_{3}$ radicals and in turn more $\mathrm{CH}_{3} \mathrm{O}_{2}$ radicals. In contrast, the low temperature chain branching reactions produce high concentrations of hydroxyl radicals and these reactions are now much less important than at lower temperatures.

At $850 \mathrm{~K}$, the reaction with the second highest positive sensitivity coefficient is the $\beta$-scission of the methoxy-methyl radical (reaction 322), to form fromaldehyde and methyl radical. This reaction prevents the addition of the alkyl radical to molecular oxygen which at low temperatures leads to the chain branching process and thus explains the positive sensitivity.

The third largest positive sensitivity at $850 \mathrm{~K}$ is the addition of $\mathrm{H}$ atom to molecular oxygen to form $\mathrm{HO}_{2}$ radical (reaction 26). This positive sensitivity is confusing as $\mathrm{H}$ atom abstraction from the fuel by $\mathrm{HO}_{2}$ radical has a high negative sensitivity coeffieient, and reaction 26 promotes the formation of $\mathrm{HO}_{2}$ radical. However, even though reaction 26 produces one reactive $\mathrm{HO}_{2}$ radical it removes a $\mathrm{H}$ atom and $\mathrm{O}_{2}$ molecule from the system, which are two reactive species at low temperatures, as observed in the high negative sensitivities to the addition reactions of alkyl and hydroperoxy alkyl radicals to $\mathrm{O}_{2}$, and $\mathrm{H}$ atom abstraction from the fuel by $\mathrm{H}$ atom. At $1200 \mathrm{~K}$, it is interesting that the addition of $\mathrm{CH}_{3} \mathrm{OCH}_{2}$ to $\mathrm{O}_{2}$ (reaction 327) exhibits the second highest sensitivity. Based on discussion of low temperature reactions in the literature, one would expect $\mathrm{CH}_{3} \mathrm{OCH}_{2} \mathrm{O}_{2}$ to decompose rapidly at this relatively high temperature so that reaction 327 would not be important. However at the high pressure of 40 atm which is similar to that found in diesel engines, the bimolecular $\mathrm{O}_{2}$ addition is enhanced over the unimolecular decomposition so that this reaction plays an important role even at relatively high temperatures.

A similar sensitivity analysis was performed on the JSR experiments of Dagaut et al. [15]. This analysis was carried out at temperatures of $800 \mathrm{~K}$ and $950 \mathrm{~K}$ to indicate sensitivity at $17 \%$ and $71.9 \%$ fuel conversion, for $0.2 \% \mathrm{DME}, \phi=2.5$ and $\mathrm{P}=10 \mathrm{~atm}$. The reaction rate constants that exhibited the highest sensitivity are shown in Figure 9. This plot shows high sensitivity coefficients to $\mathrm{H}$ atom abstraction reactions from the fuel by $\mathrm{HO}_{2}, \dot{\mathrm{O}} \mathrm{H}, \mathrm{CH}_{3} \dot{\mathrm{O}}_{2}, \dot{\mathrm{H}}$ and $\dot{\mathrm{C}} \mathrm{H}_{3}$ radicals.

Figure 9 indicates that the low temperature mechanism plays a very small role in the oxidation process of the JSR at the temperatures and pressures of this study, as is indicated by the lack of sensitivity to the low temperature oxidation reactions. However, it is incorrect to say that the low temperature mechanism plays no role in the oxidation process as indicated by the negative sensitivity coefficient to reaction 327:

$$
\mathrm{CH}_{3} \mathrm{OCH}_{2} \dot{\mathrm{O}}_{2} \stackrel{327}{\rightleftharpoons} \mathrm{CH}_{3} \mathrm{OC} \mathrm{CH}_{2}+\mathrm{O}_{2}
$$


This reaction leads to the formation of methoxy-methyl-peroxy radical, which after undergoing isomerization (reaction 333), yields two formaldehyde molecules and $\dot{\mathrm{OH}}$ radical.

$$
\begin{array}{rll}
\mathrm{CH}_{3} \mathrm{OCH}_{2} \dot{\mathrm{O}}_{2} & \stackrel{333}{\rightleftharpoons} \dot{\mathrm{CH}}_{2} \mathrm{OCH} \mathrm{O}_{2} \mathrm{H} \\
\dot{\mathrm{CH}_{2}} \mathrm{OCH}_{2} \mathrm{O}_{2} \mathrm{H} & \stackrel{334}{\rightleftharpoons} \mathrm{CH}_{2} \mathrm{O}+\mathrm{CH}_{2} \mathrm{O}+\dot{\mathrm{O} H}
\end{array}
$$

Thus, the addition of methoxy-methyl radical to $\mathrm{O}_{2}$ helps promote the rate of fuel oxidation considerably at $800 \mathrm{~K}$ and to a lesser extent at $950 \mathrm{~K}$ as it forms reactive $\mathrm{OH}$ radical.

Sensitivity to $\beta$-scission of the methoxy-methyl radical (reaction 322):

$$
\mathrm{CH}_{3} \mathrm{O} \dot{\mathrm{CH}} \mathrm{H}_{2} \stackrel{322}{\longrightarrow} \mathrm{CH}_{2} \mathrm{O}+\dot{\mathrm{CH}}_{3}
$$

shows a large positive sensitivity coefficient at $800 \mathrm{~K}$ with a lesser positive sensitivity at $950 \mathrm{~K}$. At 800 $\mathrm{K}$, the addition of $\mathrm{CH}_{3} \mathrm{O} \dot{\mathrm{C}} \mathrm{H}_{2}$ to $\mathrm{O}_{2}$ has a very important role in generating $\dot{\mathrm{O} H}$ radicals. This addition competes with $\mathrm{CH}_{3} \mathrm{OCH}_{2}$ decomposition and the two paths show large negative and positive sensitivities, respectively. As the temperature is increased to $950 \mathrm{~K}$, the role of the addition path in generating $\dot{\mathrm{O}}$ radicals is reduced, and the competition between the addition and decomposition paths is not as important to the overall reactivity of the system.

Similarily, we see a positive sensitivity associated with formyl radical decomposition (reaction 12):

$$
\mathrm{HC} \mathrm{CO}+\mathrm{M} \stackrel{12}{\longrightarrow} \dot{\mathrm{H}}+\mathrm{CO}+\mathrm{M}
$$

Again, this result is unexpected as reaction 12 generates $\dot{\mathrm{H}}$ atoms and $\mathrm{H}$ atom abstraction from the fuel promotes the oxidation process. However, formyl radical can also react with $\mathrm{O}_{2}$ (reaction 46),

$$
\mathrm{HC} \mathrm{O}+\mathrm{O}_{2} \stackrel{46}{\longrightarrow} \mathrm{CO}+\mathrm{HO}_{2}
$$

and, even under these fuel rich conditions, reaction 46 is faster than formyl decomposition, and yields $\mathrm{HO}_{2}$ radical. This radical primarily reaction with methyl radical and the fuel, and both of these reactions have high negative sensitivities.

$$
\begin{array}{rll}
\dot{\mathrm{CH}}_{3}+\mathrm{HO}_{2} & \stackrel{22}{\longrightarrow} \mathrm{CH}_{3} \dot{\mathrm{O}}+\dot{\mathrm{OH}} \\
\mathrm{CH}_{3} \mathrm{OCH}_{3}+\mathrm{HO}_{2} \stackrel{317}{\longrightarrow} \mathrm{CH}_{3} \mathrm{OC} \dot{C H}_{2}+\mathrm{H}_{2} \mathrm{O}_{2}
\end{array}
$$

Reaction 317 leads to $\mathrm{OH}$ production and chain branching through the path:

$$
\mathrm{H}_{2} \mathrm{O}_{2}+\mathrm{M} \stackrel{51}{\longrightarrow} \dot{\mathrm{O}} \mathrm{H}+\dot{\mathrm{O}} \mathrm{H}+\mathrm{M}
$$

\section{Conclusions}

A detailed chemical kinetic model has been developed to treat dimethyl ether oxidation. Concentration profiles of reactants, intermediates and products of the oxidation of DME measured in a JSR over a wide range of conditions, 1-10 atm, $0.2 \leq \phi \leq 2.5,800-1300 \mathrm{~K}$, have shown that the model can predict both primary and secondary product formation with a high degree of accuracy. The good agreement found between experimental and modeling predictions under JSR and shock-tube conditions gives us confidence in the reliability of the reaction mechanism. 
The detailed model, containing a low temperature submechanism, was used to simulate the shock tube experiments of Pfahl et al. [16] for stoichiometric mixtures of DME in air, at temperatures of 650-1300 K and reffected shock pressures of 13-40 bar. It was found that the model was able to accurately predict total ignition delay times and first stage or "cool-flame" ignition times. The underprediction of ethene by the model as shown in Figure 6 indicates that there may be an alternative path to ethene formation not included in the model.

\section{Acknowledgement}

The computational portions of this work were performed under the auspices of the U.S. Department of Energy by the Lawrence Livermore National Laboratory under contract No. W-7405-ENG-48. 


\section{References}

[1] Rouhi, A. M. Chem. and Eng. News., pp. 37-39, May 29, (1995).

[2] Brooks, R. WARD's Engine and Vehicle Tech. Update, p. 3, July 15, (1995).

[3] Green, C. J.; Cockshutt, N. A. and King, L. Society of Automotive Engineers publication SAE902155 (1990).

[4] Benson, S. W., J. Chem. Phys. 25:27-31, (1956).

[5] Benson, S. W., and Jain, D. V. S., J. Chem. Phys. 31:1008-1017, (1959).

[6] Anderson, K. H., and Benson, S. W., J. Chem. Phys. 36:2320-2323, (1962).

[7] McKenney, D. J., and Laidler, K. J., Can. J. Chem. 41:1984-1992, (1963).

[8] McKenney, D. J., Wojciechowski, B. W., and Laidler, K. J., Can. J. Chem. 41:1993-2008, (1963).

[9] McKenney, D. J., and Laidler, K. J., Can. J. Chem. 41:2009-2019, (1963).

[10] Pacey, P. D., Can. J. Chem. 53:2742-2747, (1975).

[11] Aronowitz, D., and Naegeli, D., Int. J. Chem. Kinet. 9:471-479, (1977).

[12] Held, A. M., Manthorne, K. C., Pacey, P. D., and Reinholdt, H. P., Can. J. Chem. 55:4128-4134, (1977).

[13] Manthorne, K. C., and Pacey, P. D., Can. J. Chem. 56:1307-1310, (1978).

[14] Sehested, J., Mogelberg, T, Wallington, T. J., Kaiser, E. W. and Nielsen, O. J., J. Phys. Chem. 100:17218-17225, (1996).

[15] Dagaut, P, Boettner, J-C. and Cathonnet, M. Twenty-Sixth Symposium (International) on Combustion., in press, The Combustion Institute, Pittsburgh, 1996.

[16] Pfahl, U., Fieweger, K. and Adomeit, G. Twenty-Sixth Symposium (International) on Combustion., in press, The Combustion Institute, Pittsburgh, 1996.

[17] Lund, C. M. and Chase, L., "HCT - A General Computer Program for Calculating Time-Dependent Phenomena Involving One-Dimensional Hydrodynamics, Transport, and Detailed Chemical Kinetics," Lawrence Livermore National Laboratory report UCRL-52504, revised (1995).

[18] Ritter, E. R. and Bozzelli, J. W., Int. J. Chem. Kinet. 23:767 (1991).

[19] Lay, T., Bozzelli, J. W., Dean, A. M., and Ritter, E. R. J. Phys. Chem. 99:14514, (1995).

[20] Dean, A. M., J. Phys. Chem. 89:4600, (1985).

[21] Dean, A. M., Bozzelli, J. M. and Ritter, J. W. Combust. Sci. Tech. 80:63-85, (1991).

[22] Batt, L., Alvarado-Salinas, G., Reid, I. A. B., Robinson, C., and Smith, D. B. Twenty Fifth Symposium (International) on Combustion, Combustion Institute, Pittsburgh, 1982, p. 81.

[23] Mallard, W. G., Westley, F., Herron, J. T., Hampson, R. F., NIST Chemical Kinetics Database Ver. 6.0

NIST Standard Reference Data, Gaithersburg,MD (1994).

[24] Perry, R. A, Atkinson, R., and Pitts, J. N., Jr., J. Chem. Phys. 67:611, (1977).

[25] Tully, F. P., and Droege, A. T., J. Phys. Chem. 19:251-259, (1987).

[26] Wallington, T. J., Liu, R., Dagaut, P., and Kurylo, M. J., Int. J. Chem. Kinet. 20:41-49, (1988).

[27] Nelson, L., Rattigan, O., Neavyn, R., and Sidebottom, H., Int. J. Chem. Kinet. 22:1111, (1990).

[28] Droege, A. T., and Tully, F. P., J. Phys. Chem. 90:1949-1954, (1986).

[29] Arif, M., Dellinger, B. and Taylor, P. H. J. Phys. Chem. x:xxx-xxx, (1997).

[30] Meagher, J. F., Kim, P., Lee, J. H., and Timmons, R. B., J. Phys. Chem. 78:2650-2657, (1974).

[31] Faubel, C., Hoyermann, K., Strofer, E., and Wagner, H. Gg., Ber. Bunsenges. Phys. Chem. 83:532, (1979).

[32] Lee, J. H., Machen, R. C., Nava, D. F., and Stief, L. J., J. Chem. Phys. 74:2839, (1981).

[33] Walker, R. W., Twenty-Second Symposium (International) on Combustion, Combustion Institute, Pittsburgh, 1988, pp. 883-892.

[34] Gray, P., and Herod, A. A., Trans. Faraday Soc. 64:2723, (1968). 
[35] Arthur, N. L., Gray, P., and Herod, A. A., Can. J. Chem. 47:1347, (1969).

[36] Tsang, W. J. Phys. Chem. Ref. Data 16:471, (1987).

[37] LeFevre, H. F., Meagher, J. F., and Timmons, R. B., Int. J. Chem. Kinet. 4:103, (1972).

[38] Faubel, C., Hoyermann, K., and Wagner, H. Gg., Z. Phys. Chem. (Neue Folge) 130:1, (1982).

[39] Liu, R., Dagaut, P., Huie, R. E., and Kurylo, M. J., Int. J. Chem. Kinet. 22:711, (1990).

[40] Herron, J. T. J. Phys. Chem. Ref. Data 17:967, (1988).

[41] Benson, S. W., Thermochemical Kinetics. John Wiley and Sons, Inc., New York 1976.

[42] Loucks, L. F. and Laidler, K. J. Can. J. Chem. 45:2767-2773 (1967).

[43] Bozzelli, J. W. and Pitz, W. J. Twenty Fifth Symposium (International) on Combustion, Combustion Institute, Pittsburgh, 1994, p. 783.

[44] Curran, H. J., Gaffuri, P., Pitz, W. J., and Westbrook, C. K. Combust. Flame submiited March, (1997).

[45] Baulch, D. L., Cobos, C. J., Cox, R. A., Esser, C., Frank, P., Just, Th. Kerr, J. A., Pilling, M. J., Troe, J, Walker, R. W., Warnatz, J. J. Phys. Chem. Ref. Data 21:411-429 (1992).

[46] Walter, D., Grotheer, H-H, Davies, J. W., Pilling, M. J. and Wagner, A. F. Twenty-Thind Symposium (International) on Combustion, Combustion Institute, Pittsburgh, 1991, p. 107. 


\begin{tabular}{|c|c|c|c|}
\hline Species & $\begin{array}{c}\mathrm{H}_{\mathrm{f}}^{\circ} \mathrm{ag} \mathrm{K} \\
(\mathrm{kcal} / \mathrm{mol})\end{array}$ & $\begin{array}{l}\mathrm{S}_{\mathrm{f}}^{\circ} 298 \mathrm{~K} \\
\text { (cal/mol-K) }\end{array}$ & $\begin{array}{l}\mathrm{C}_{\mathrm{p}} @ 300 \mathrm{~K} \\
(\mathrm{cal} / \mathrm{mol}-\mathrm{K})\end{array}$ \\
\hline $\mathrm{CH}_{3} \mathrm{OCH}_{3}$ & -43.40 & 63.76 & 15.78 \\
\hline $\mathrm{CH}_{3} \mathrm{O} \dot{\mathrm{C}} \mathrm{H}_{2}$ & 2.00 & 67.28 & 16.30 \\
\hline $\mathrm{CH}_{3} \mathrm{OCH}_{2} \mathrm{O}_{2} \mathrm{H}$ & -72.03 & 84.54 & 24.83 \\
\hline $\mathrm{CH}_{3} \mathrm{OCH}_{2} \dot{\mathrm{O}}$ & -34.47 & 73.94 & 18.41 \\
\hline $\mathrm{CH}_{3} \mathrm{OCHO}$ & -84.39 & 71.53 & 17.13 \\
\hline $\mathrm{CH}_{3} \mathrm{OCH}_{2} \dot{\mathrm{O}}_{2}$ & -35.93 & 84.76 & 22.78 \\
\hline$\dot{\mathrm{C}} \mathrm{H}_{2} \mathrm{OCH}_{2} \mathrm{O}_{2} \mathrm{H}$ & -26.63 & 86.68 & 25.35 \\
\hline$\dot{\mathrm{O}}_{2} \mathrm{CH}_{2} \mathrm{OCH}_{2} \mathrm{O}_{2} \mathrm{H}$ & -64.56 & 104.16 & 31.83 \\
\hline $\mathrm{HO}_{2} \mathrm{CH}_{2} \mathrm{OCHO} \mathrm{CH}_{2} \mathrm{H}$ & -54.26 & 105.05 & 34.50 \\
\hline $\mathrm{HO}_{2} \mathrm{CH}_{2} \mathrm{OCHO}$ & -113.02 & 90.93 & 26.18 \\
\hline $\mathrm{OCH}_{2} \mathrm{OCHO}$ & -75.46 & 80.33 & 19.76 \\
\hline
\end{tabular}

Table 1: Thermodynamic properties for selected species 


\begin{tabular}{|c|c|c|c|c|c|}
\hline No. & Reaction & $\mathcal{A}$ & $\boldsymbol{n}$ & $\varepsilon_{a}$ & Citation \\
\hline $\mathbf{3 1 3}$ & $\mathrm{CH}_{3} \mathrm{OCH}_{3}=\mathrm{CH}_{3} \mathrm{O}+\mathrm{CH}_{3}$ & $1.380 \mathrm{E}+52$ & -10.85 & 96640 . & $t^{2}$ \\
\hline 313 & $\mathrm{CH}_{3} \mathrm{OCH}_{3}=\mathrm{CH}_{3} \mathrm{O}+\dot{\mathrm{C}} \mathrm{H}_{3}$ & $3.240 \mathrm{E}+41$ & -7.46 & 92480. & $t^{b}$ \\
\hline 313 & $\mathrm{CH}_{3} \mathrm{OCH}_{3}=\mathrm{CH}_{3} \mathrm{O}+\mathrm{CH}_{3}$ & $1.450 \mathrm{E}+34$ & -5.32 & 89441. & $\dagger^{c}$ \\
\hline 314 & $\mathrm{CH}_{3} \mathrm{OCH}_{3}+\mathrm{OH}=\mathrm{CH}_{3} \mathrm{OCH}_{2}+\mathrm{H}_{2} \mathrm{O}$ & $1.402 \mathrm{E}+08$ & 1.61 & -35 . & $t$ \\
\hline 315 & $\mathrm{CH}_{3} \mathrm{OCH}_{3}+\mathrm{H}=\mathrm{CH}_{3} \mathrm{OCH}_{2}+\mathrm{H}_{2}$ & $11.54 \mathrm{E}+00$ & 4.03 & 2048. & $t$ \\
\hline 316 & $\mathrm{CH}_{3} \mathrm{OCH}_{3}+\mathrm{O}=\mathrm{CH}_{3} \mathrm{OCH}_{2}+\mathrm{OH}$ & $1.855 \mathrm{E}-03$ & 5.29 & -109 & $t$ \\
\hline 317 & $\mathrm{CH}_{3} \mathrm{OCH}_{3}+\mathrm{HO}_{2}=\mathrm{CH}_{3} \mathrm{OC} \mathrm{H}_{2}+\mathrm{H}_{2} \mathrm{O}_{2}$ & $1.000 E+13$ & 0.00 & 17686. & $\dagger$ \\
\hline 318 & $\mathrm{CH}_{3} \mathrm{OCH}_{3}+\mathrm{CH}_{3} \dot{\mathrm{O}}_{2}=\mathrm{CH}_{3} \mathrm{OCH}_{2}+\mathrm{CH}_{3} \mathrm{O}_{2} \mathrm{H}$ & $1.000 \mathrm{E}+13$ & 0.00 & 17686. & $t$ \\
\hline 319 & $\mathrm{CH}_{3} \mathrm{OCH}_{3}+\dot{\mathrm{C}} \mathrm{H}_{3}=\mathrm{CH}_{3} \mathrm{OCH}_{2}+\mathrm{CH}_{4}$ & $2.260 \mathrm{E}-05$ & 5.35 & 5812. & $t$ \\
\hline 320 & $\mathrm{CH}_{9} \mathrm{OCH}_{3}+\mathrm{O}_{2}=\mathrm{CH}_{3} \mathrm{OC} \dot{C H}_{2}+\mathrm{HO}_{2}$ & $4.100 \mathrm{E}+13$ & 0.00 & 44911. & t \\
\hline 321 & $\mathrm{CH}_{3} \mathrm{OCH}_{3}+\mathrm{CH}_{3} \mathrm{O}=\mathrm{CH}_{3} \mathrm{OC} \mathrm{CH}_{2}+\mathrm{CH}_{3} \mathrm{OH}$ & $6.020 \mathrm{E}+11$ & 0.00 & 4074. & $\dagger$ \\
\hline 322 & $\mathrm{CH}_{3} \mathrm{OC} \mathrm{CH}_{2}=\dot{\mathrm{C}} \mathrm{H}_{3}+\mathrm{CH}_{2} \mathrm{O}$ & $1.600 \mathrm{E}+13$ & 0.00 & 25500. & [42] \\
\hline 323 & $\mathrm{CH}_{3} \mathrm{OC} \mathrm{CH}_{2}+\mathrm{CH}_{3} \mathrm{O}=\mathrm{CH}_{3} \mathrm{OCH}_{3}+\mathrm{CH}_{2} \mathrm{O}$ & $2.410 \mathrm{E}+13$ & 0.00 & 0. & $t$ \\
\hline 324 & $\mathrm{CH}_{3} \mathrm{OCH}_{2}+\mathrm{CH}_{2} \mathrm{O}=\mathrm{CH}_{3} \mathrm{OCH}_{3}+\mathrm{HCO}$ & $5.490 \mathrm{E}+03$ & 2.80 & 5862. & $\dagger$ \\
\hline 325 & $\mathrm{CH}_{3} \mathrm{OC} \mathrm{H}_{2}+\mathrm{CH}_{3} \mathrm{CHO}=\mathrm{CH}_{3} \mathrm{OCH}_{3}+\mathrm{CH}_{3} \dot{\mathrm{CO}}$ & $1.260 \mathrm{E}+12$ & 0.00 & 8499. & $t$ \\
\hline 326 & $\mathrm{CH}_{3} \mathrm{OCH}_{2}+\mathrm{HO}_{2}=\mathrm{CH}_{3} \mathrm{OCH}_{2} \dot{\mathrm{O}}+\mathrm{OH}$ & $9.640 \mathrm{E}+12$ & 0.00 & 0. & $\dagger$ \\
\hline 327 & $\mathrm{CH}_{3} \mathrm{OCH}_{2} \dot{\mathrm{O}}_{2}=\mathrm{CH}_{3} \mathrm{OC}_{2} \mathrm{CH}_{2}+\mathrm{O}_{2}$ & $4.681 E+17$ & -1.20 & 38240. & $\dagger$ \\
\hline 328 & $\mathrm{CH}_{3} \mathrm{OCH}_{2} \mathrm{O}_{2}+\mathrm{CH}_{3} \mathrm{OCH}_{3}=\mathrm{CH}_{3} \mathrm{OCH}_{2} \mathrm{O}_{2} \mathrm{H}+\mathrm{CH}_{3} \mathrm{OCH}_{2}$ & $1.000 \mathrm{E}+13$ & 0.00 & 17686. & $\dagger$ \\
\hline 329 & $\mathrm{CH}_{3} \mathrm{OCH}_{2} \dot{\mathrm{O}}_{2}+\mathrm{CH}_{2} \mathrm{O}=\mathrm{CH}_{3} \mathrm{OCH}_{2} \mathrm{O}_{2} \mathrm{H}+\mathrm{HCO}$ & $1.990 \mathrm{E}+12$ & 0.00 & 11665. & $\dagger$ \\
\hline 330 & $\mathrm{CH}_{3} \mathrm{OCH}_{2} \mathrm{O}_{2}+\mathrm{CH}_{3} \mathrm{CHO}=\mathrm{CH}_{3} \mathrm{OCH}_{2} \mathrm{O}_{2} \mathrm{H}+\mathrm{CH}_{3} \mathrm{CO}$ & $2.800 \mathrm{E}+12$ & 0.00 & 13600. & $\dagger$ \\
\hline 331 & $\mathrm{CH}_{3} \mathrm{OCH}_{2} \mathrm{O}_{2} \mathrm{H}=\mathrm{CH}_{3} \mathrm{OCH}_{2} \mathrm{O}+\mathrm{OH}$ & $1.828 E+20$ & -1.54 & 44150. & $\dagger$ \\
\hline 332 & $\mathrm{CH}_{3} \mathrm{OCH}_{2} \mathrm{O}=\mathrm{CH}_{3} \mathrm{O}+\mathrm{CH}_{2} \mathrm{O}$ & $6.475 \mathrm{E}+12$ & -0.13 & 14870. & $\dagger$ \\
\hline 333 & $\mathrm{CH}_{3} \mathrm{OCH}_{2} \dot{\mathrm{O}}_{2}=\dot{\mathrm{C}} \mathrm{H}_{2} \mathrm{OCH}_{2} \mathrm{O}_{2} \mathrm{H}$ & $7.420 \mathrm{E}+11$ & 0.00 & 18560. & t \\
\hline 334 & $\dot{\mathrm{C}} \mathrm{H}_{2} \mathrm{OCH}_{2} \mathrm{O}_{2} \mathrm{H}=\mathrm{CH}_{2} \mathrm{O}+\mathrm{CH}_{2} \mathrm{O}+\mathrm{OH}$ & $1.250 \mathrm{E}+13$ & 0.00 & 18160. & t \\
\hline 335 & $\mathrm{O}_{2} \mathrm{CH}_{2} \mathrm{OCH}_{2} \mathrm{O}_{2} \mathrm{H}+\dot{\mathrm{CH}}_{2} \mathrm{OCH}_{2} \mathrm{O}_{2} \mathrm{H}+\mathrm{O}_{2}$ & $4.993 \mathrm{E}+17$ & -1.22 & 38260. & $t$ \\
\hline 336 & $\mathrm{O}_{2} \mathrm{CH}_{2} \mathrm{OCH}_{2} \mathrm{O}_{2} \mathrm{H}=\mathrm{HO}_{2} \mathrm{CH}_{2} \mathrm{OCHO}+\mathrm{OH}$ & $3.710 \mathrm{E}+11$ & 0.00 & 16300. & t \\
\hline 337 & $\mathrm{HO}_{2} \mathrm{CH}_{2} \mathrm{OCHO}=\mathrm{OCH}_{2} \mathrm{OCHO}+\mathrm{OH}$ & $1.013 \mathrm{E}+20$ & -1.46 & 44090 . & t \\
\hline 338 & $\mathrm{OCH}_{2} \mathrm{OCHO}=\mathrm{CH}_{2} \mathrm{O}+\mathrm{HCO}_{2}$ & $5.048 \mathrm{E}+16$ & -1.60 & 15400. & $\dagger$ \\
\hline
\end{tabular}

Table 2: Rate expressions for critical reactions in dimethyl ether oxidation; $\mathrm{cm}^{3} / \mathrm{mol} / \mathrm{sec} / \mathrm{cal}$ units. $\dagger:$ this study, see text. $a=1 \mathrm{~atm}, \mathrm{~b}=10 \mathrm{~atm}, \mathrm{c}=40 \mathrm{~atm}$ 

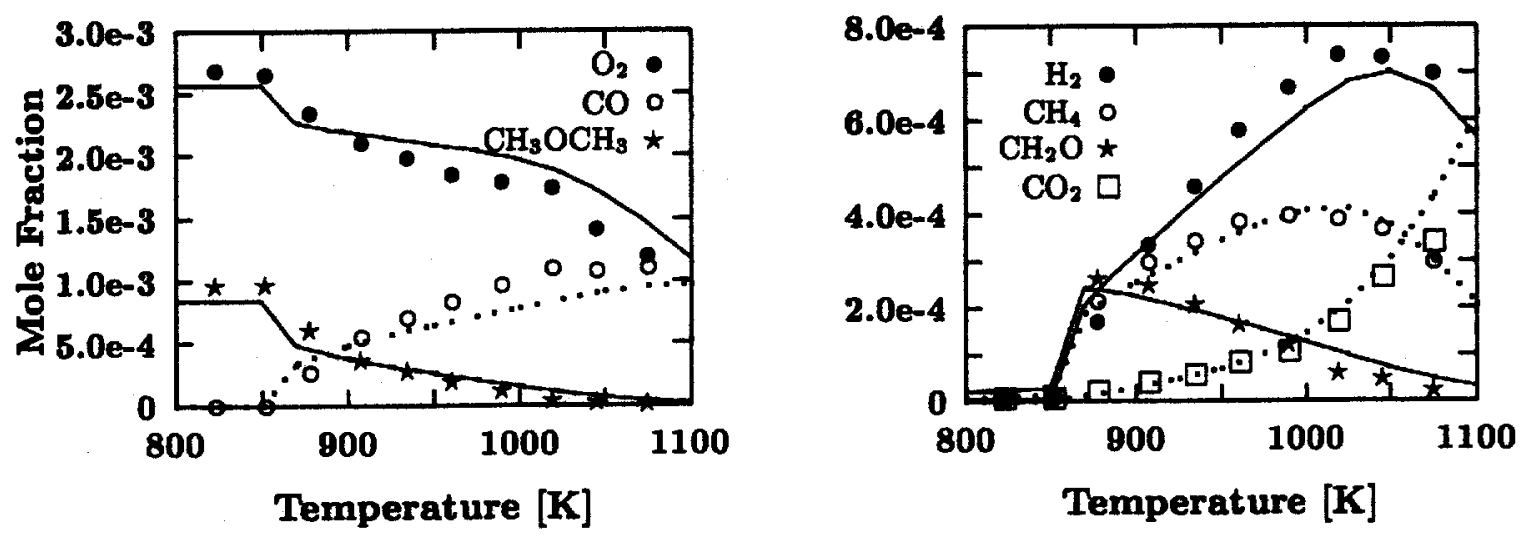

Figure 2: Experimental results (points) [15] versus model predictions (lines) at $0.1 \% \mathrm{DME}, \phi=1.0$, $P=10$ atm, $\tau=1 \mathrm{~s}$. Dotted lines correspond to open circles.
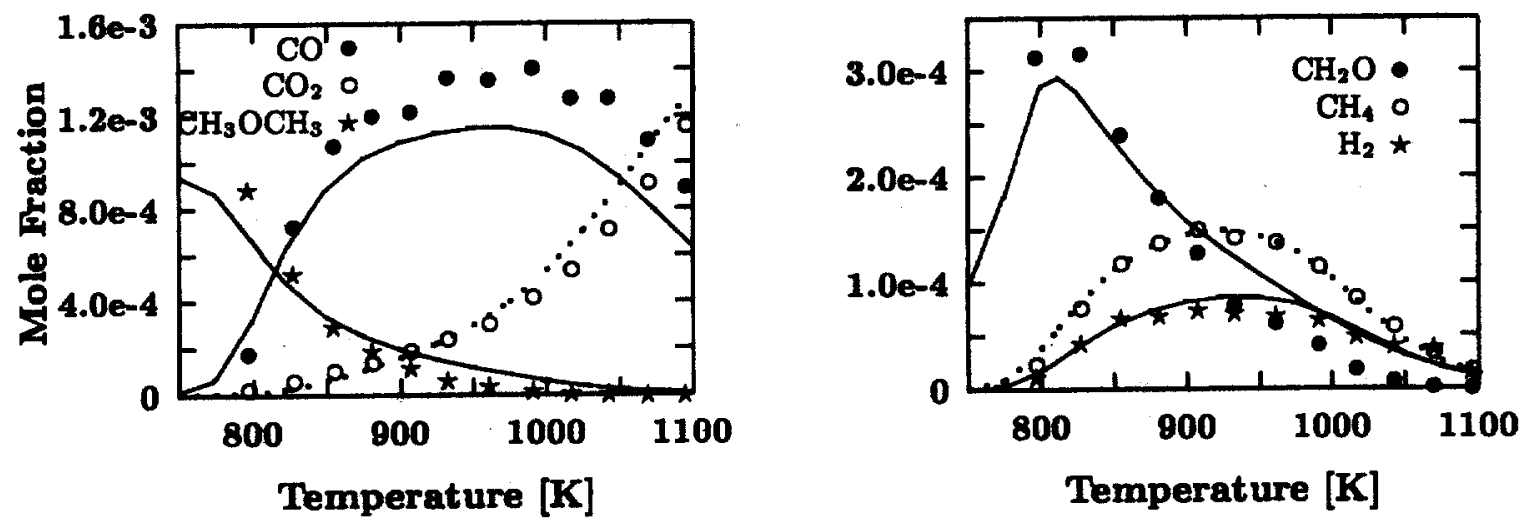

Figure 3: Experimental results (points) [15] versus model predictions (lines) at $0.1 \% \mathrm{DME}, \phi=0.2$, $P=10$ atm, $\tau=1$ s. Dotted lines correspond to open circles. 

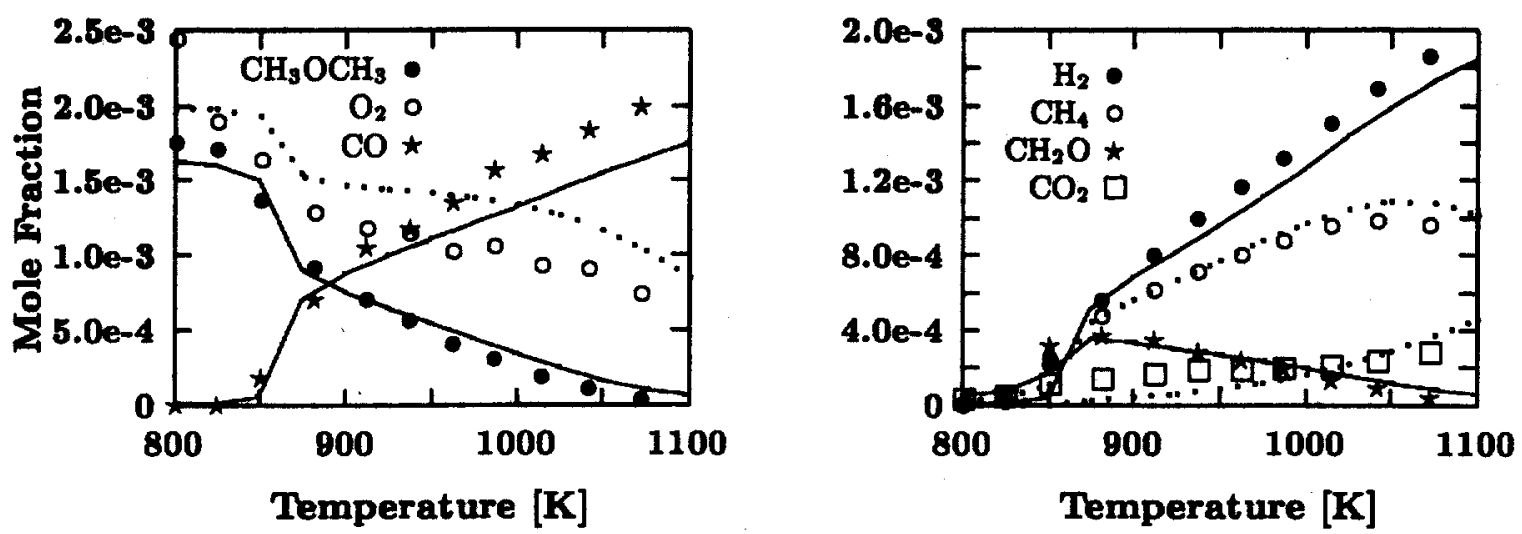

Figure 4: Experimental results (points) [15] versus model predictions (lines) at $0.2 \% \mathrm{DME}, \phi=2.5$, $\mathrm{P}=10$ atm, $\tau=1 \mathrm{~s}$. Dotted lines correspond to open circles.
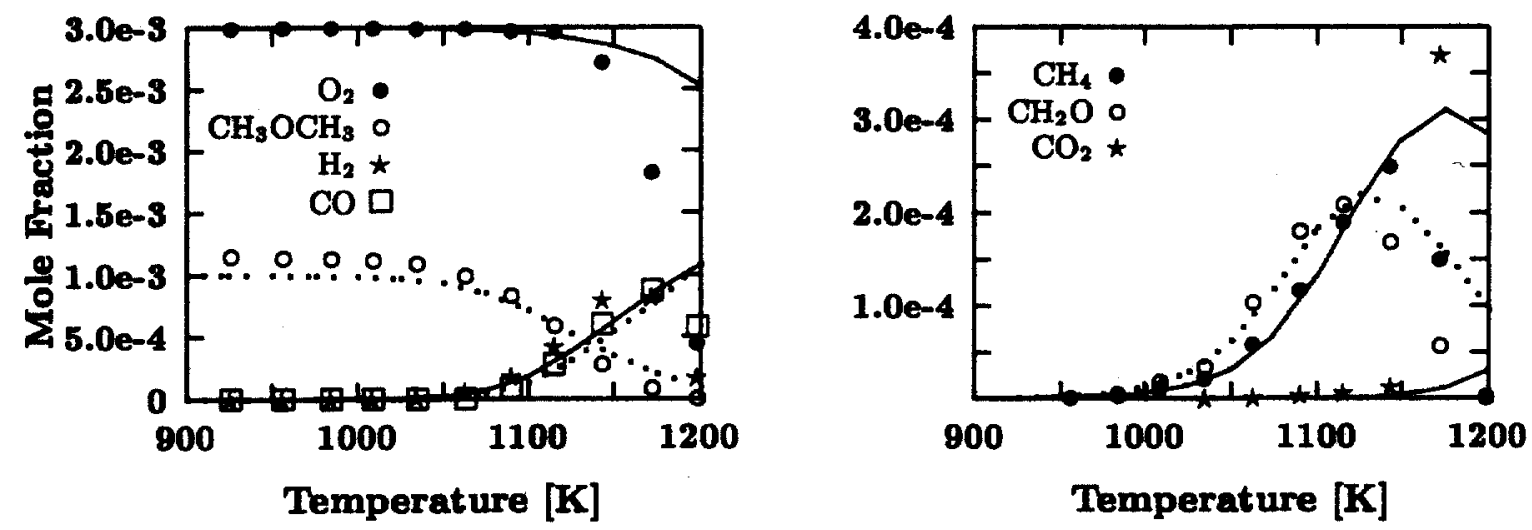

Figure 5: Experimental results (points) [15] versus model predictions (lines) at $0.1 \% \mathrm{DME}, \phi=1.0$, $\mathrm{P}=1 \mathrm{~atm}, \tau=0.1 \mathrm{~s}$. Dotted lines correspond to open symbols. 

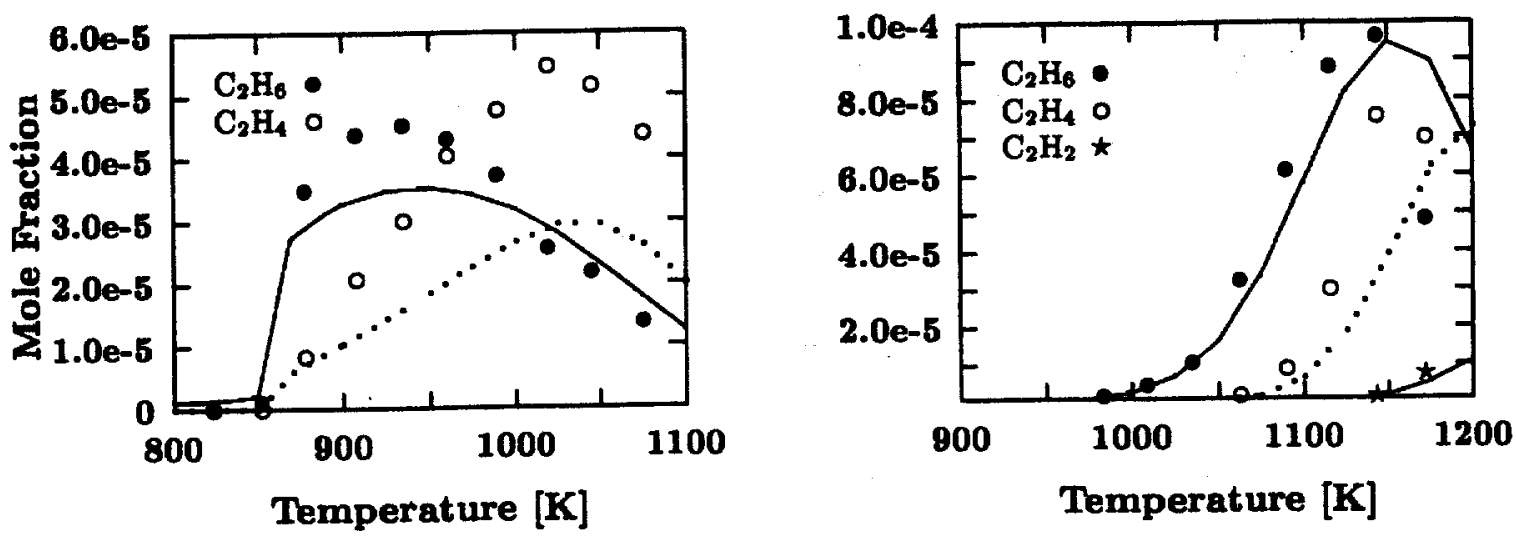

Figure 6: Experimental results (points) [15] versus model predictions (lines) at $0.1 \% \mathrm{DME}, \phi=1.0,(\mathrm{a})$ $\mathrm{P}=10$ atm, $\tau=1 \mathrm{~s}$ and (b) $\mathrm{P}=1 \mathrm{~atm}, \tau=0.1 \mathrm{~s}$. Dotted lines correspond to open symbols.

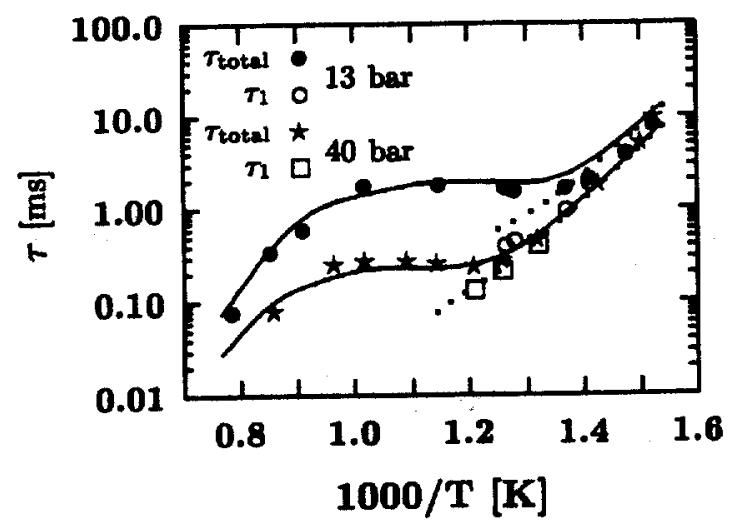

Figure 7: Experimental ignition delays (points) [16] versus model predictions (lines) for stoichiometric dimethyl ether oxidation in air. Dotted lines correspond to open symbols. 


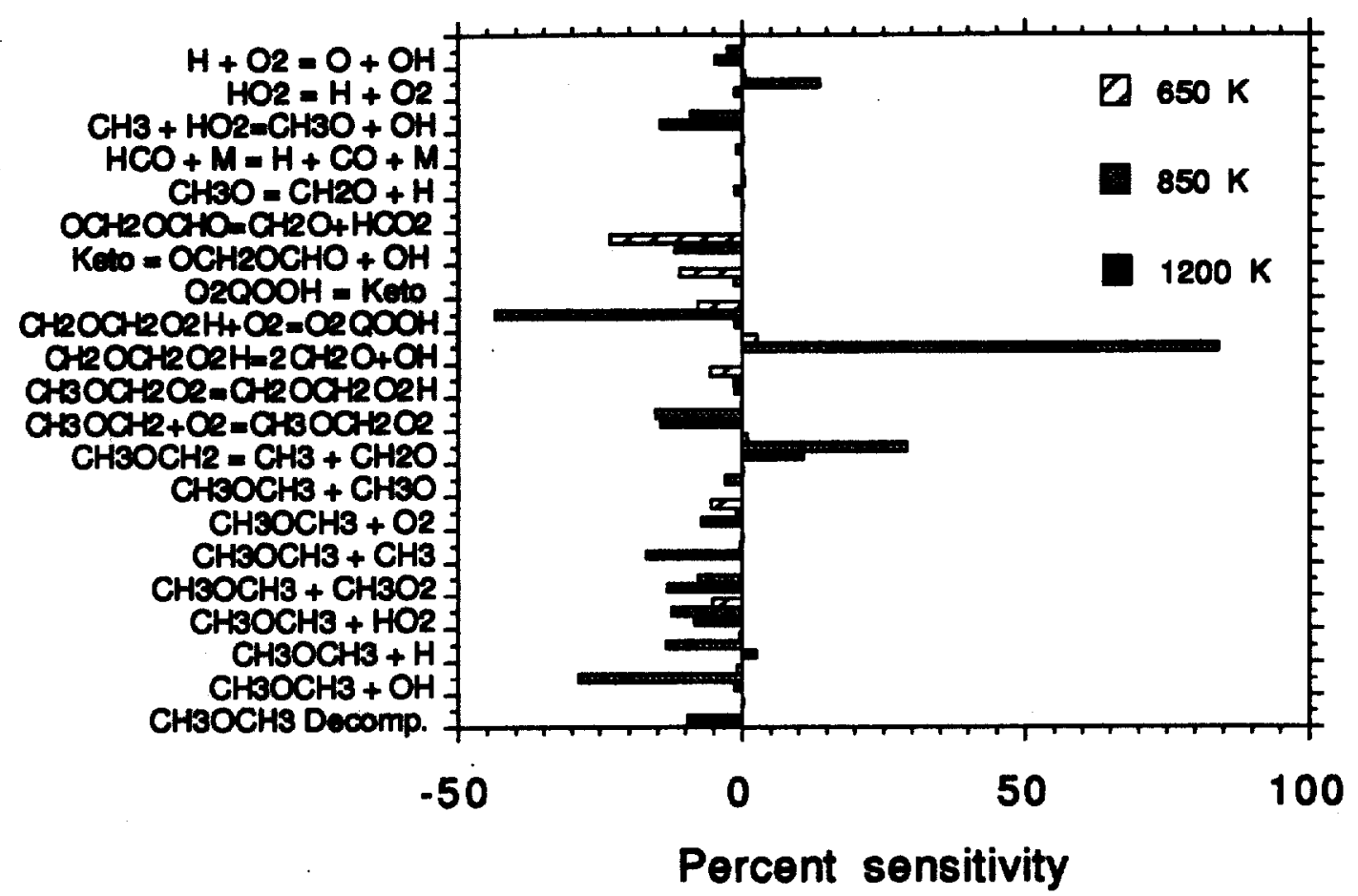

Figure 8: Sensitivity coefficients for dimethyl ether oxidation in a shock tube. Stoichiometric fuel in air, $P_{5}=40$ bar

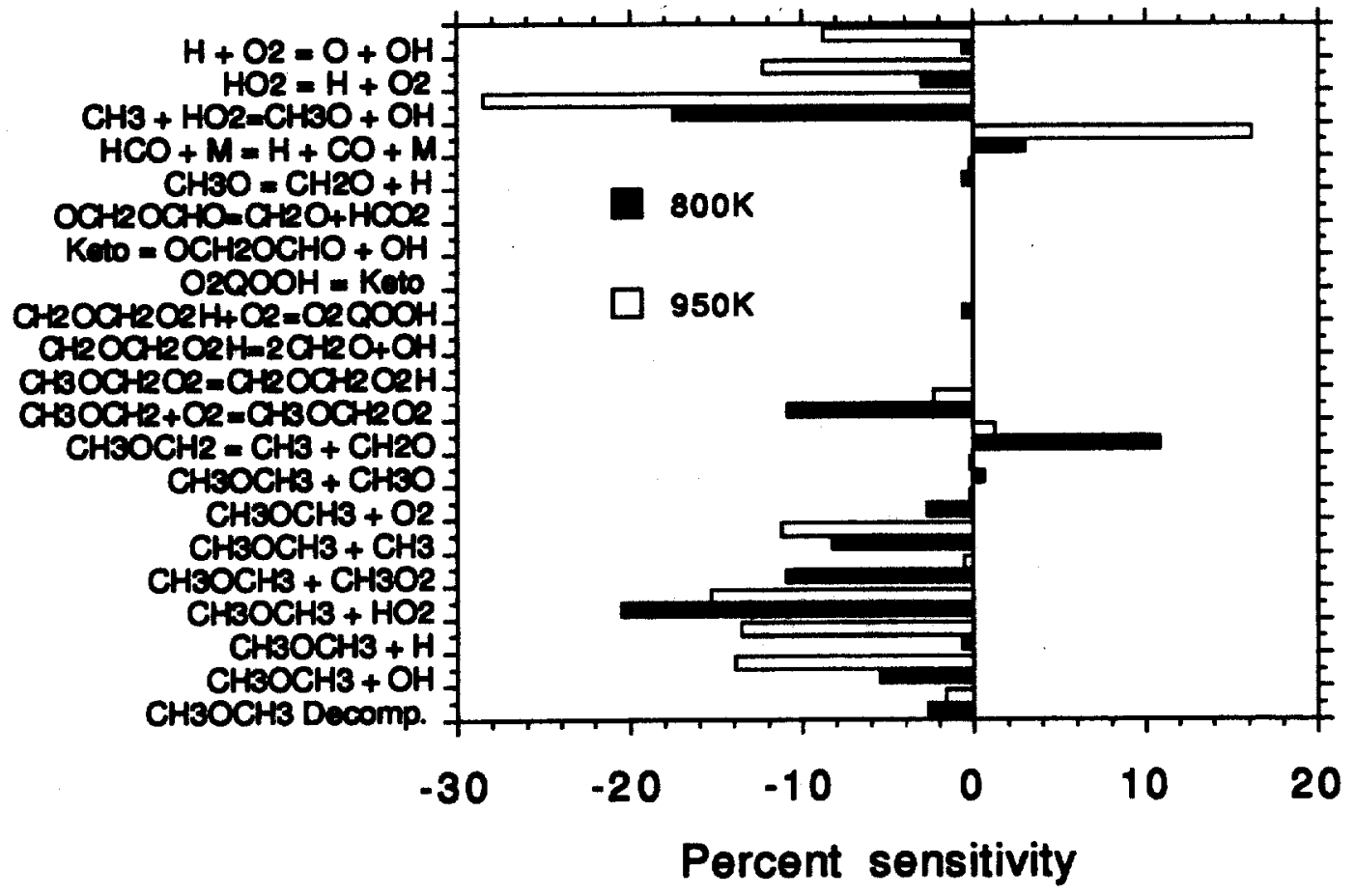

Figure 9: Sensitivity coefficients for dimethyl ether oxidation in a JSR. $0.2 \% \mathrm{DME}, \phi=2.5, \mathrm{P}=10$ atm, $\tau=1.0 \mathrm{~s}$ 


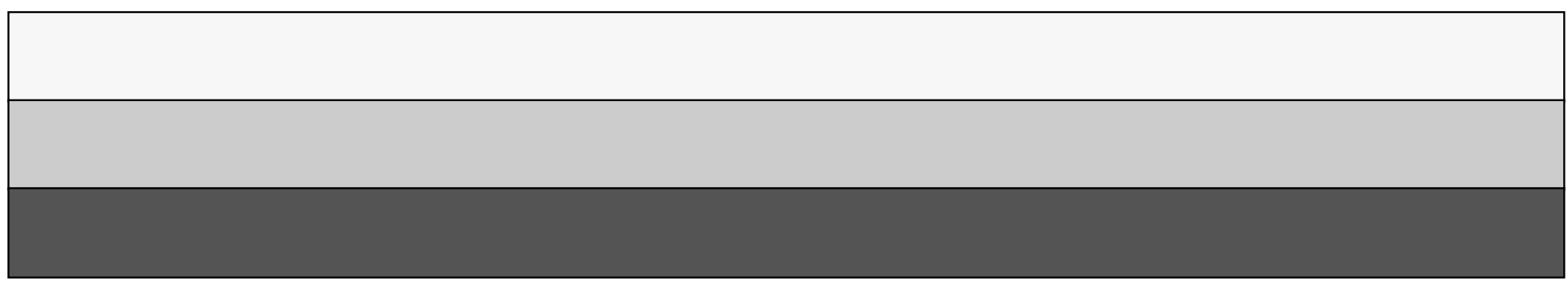

